\title{
Revisiting enigmatic cortical calretinin-expressing interneurons
}

\author{
Bruno Cauli ${ }^{1,2,3}$, Xiaojuan Zhou ${ }^{4}$, Ludovic Tricoire ${ }^{1,2,3}$, Xavier Toussay ${ }^{1,2,3}$ and Jochen F Staiger ${ }^{4}$ \\ 1 Sorbonne Universités, UPMC University Paris 06, UM CR18, Neuroscience Paris Seine, Paris, France \\ ${ }^{2}$ Centre National de la Recherche Scientifique, UMR 8246, Neuroscience Paris Seine, Paris, France \\ ${ }^{3}$ Institut National de la Santé et de la Recherche Médicale, UMR-S 1130, Neuroscience Paris Seine, Paris, France \\ ${ }^{4}$ Institute for Neuroanatomy, UMG, Georg-August-University Göttingen, Göttingen, Germany
}

\section{Edited by:}

Zsofia Magloczky, Hungarian

Academy of Sciences, Hungary

Reviewed by:

José A. Armengol, University Pablo

de Olavide, Spain

Fiorenzo Conti, Universita

Politecnica delle Marche, Italy

*Correspondence:

Bruno Cauli, CNRS-UPMC,

Neuroscience Paris Seine, 9 Quai

Saint Bernard, 75005 Paris, France

e-mail: bruno.cauli@snv.jussieu.fr;

Jochen F. Staiger, Institute for

Neuroanatomy, UMG,

Georg-August-University Göttingen,

37075 Göttingen, Germany

e-mail: jochen.staiger@

med.uni-goettingen.de
Cortical calretinin (CR)-expressing interneurons represent a heterogeneous subpopulation of about $10-30 \%$ of GABAergic interneurons, which altogether total ca. $12-20 \%$ of all cortical neurons. In the rodent neocortex, CR cells display different somatodendritic morphologies ranging from bipolar to multipolar but the bipolar cells and their variations dominate. They are also diverse at the molecular level as they were shown to express numerous neuropeptides in different combinations including vasoactive intestinal polypeptide (VIP), cholecystokinin (CCK), neurokinin B (NKB) corticotrophin releasing factor (CRF), enkephalin (Enk) but also neuropeptide $Y$ (NPY) and somatostatin (SOM) to a lesser extent. CR-expressing interneurons exhibit different firing behaviors such as adapting, bursting or irregular. They mainly originate from the caudal ganglionic eminence (CGE) but a subpopulation also derives from the dorsal part of the medial ganglionic eminence (MGE). Cortical GABAergic CR-expressing interneurons can be divided in two main populations: VIP-bipolar interneurons deriving from the CGE and SOM-Martinotti-like interneurons originating in the dorsal MGE. Although bipolar cells account for the majority of CR-expressing interneurons, the roles they play in cortical neuronal circuits and in the more general metabolic physiology of the brain remained elusive and enigmatic. The aim of this review is, firstly, to provide a comprehensive view of the morphological, molecular and electrophysiological features defining this cell type. We will, secondly, also summarize what is known about their place in the cortical circuit, their modulation by subcortical afferents and the functional roles they might play in neuronal processing and energy metabolism.

Keywords: neuropeptides, neocortex, neocortical circuits, embryonic and fetal development, neuroenergetics

\section{INTRODUCTION: WHAT ARE THE CORTICAL CALRETININ-EXPRESSING INTERNEURONS?}

Cortical calretinin (CR) expressing interneurons represent a heterogeneous subpopulation of about $10-30 \%$ of GABAergic interneurons (Kubota et al., 1994; Gonchar and Burkhalter, 1997; Tamamaki et al., 2003). They display different somatodendritic morphologies ranging from bipolar to multipolar (Jacobowitz and Winsky, 1991; Kubota et al., 1994; Gonchar and Burkhalter, 1997; Gonchar et al., 2008; Caputi et al., 2009). They are also diverse at the molecular level as they express numerous neuropeptides in different combinations including vasoactive intestinal polypeptide (VIP) (Kubota et al., 1994; Cauli et al., 1997), cholecystokinin (CCK) (Cauli et al., 1997; Gonchar et al., 2008), neurokinin B (NKB) (Kaneko et al., 1998; Gallopin et al., 2006) corticotrophin releasing factor (CRF) (Gallopin et al., 2006; Kubota et al., 2011), enkephalin (Enk) (Taki et al., 2000; Férézou et al., 2007), but also to a lesser extent and in a species-dependent manner neuropeptide Y (NPY) (Cauli et al., 1997; Wang et al., 2004; Gonchar et al., 2008) and somatostatin (SOM) (Cauli et al., 1997; Wang et al., 2004; Xu et al., 2010b).
CR-expressing interneurons also exhibit different firing behaviors such as adapting, bursting or irregular (Kawaguchi and Kubota, 1996; Cauli et al., 1997, 2000; Porter et al., 1998; Wang et al., 2002; Karagiannis et al., 2009). They mainly originate from the caudal ganglionic eminence (CGE) (Xu et al., 2004; Butt et al., 2005) but a subpopulation also derives from the dorsal part of the medial ganglionic eminence (MGE) (Fogarty et al., 2007; Xu et al., 2008). Cortical GABAergic CR+ interneurons can be divided in two main populations: VIP-bipolar interneurons deriving from the CGE and SOM-Martinotti-like interneurons originating in the dorsal MGE. In the rodent neocortex, bipolar cells account for the majority of $\mathrm{CR}+$ interneurons, therefore, we consider them as our main focus of the review. Due to the relatively few and scattered studies of $\mathrm{CR}+$ interneurons, their inputs and outputs, the roles they play in cortical neuronal circuits as well as neuroenergetics of the brain remained elusive and enigmatic until quite recently. The aim of this review is, firstly, to provide a comprehensive view of the morphological, molecular and electrophysiological features defining cortical bipolar CR-expressing interneurons. We will, secondly, also review their places in the 
cortical circuit, their modulations by subcortical afferents and the functional roles they might play in neuronal processing and energy metabolism. We are convinced that the synthesis of recent data on bipolar CR-expressing interneurons will show that they are much less enigmatic than they appeared roughly 25 years ago (Peters and Harriman, 1988).

\section{EMBRYONIC ORIGINS}

Unlike glutamatergic neurons which are born in the ventricular zone of the telencephalic vesicle and then migrate radially (Molyneaux et al., 2007; Rakic, 2007), most of the GABAergic interneurons derive from one proliferative region called ganglionic eminence (GE) located in the ventral part of the telencephalon (Wonders and Anderson, 2006; Batista-Brito and Fishell, 2009; Bartolini et al., 2013). Once born, interneuron precursors migrate first dorsally, guided by attracting and repulsive molecular cues, then tangentially toward neocortex and hippocampus along two main migratory streams (Chedotal and Rijli, 2009; Marin, 2013). They eventually acquire their final laminar location by penetrating the cortical plate. Anatomically, the GE is subdivided in three main regions, the medial, lateral, and caudal GE (MGE, LGE, and CGE, Figure 1). Cortical and hippocampal interneurons derive mainly from the MGE and CGE, while the LGE is the major contributor of GABAergic interneurons of striatum and basal forebrain structures. The preoptic area (Figure 1) has recently been described as another source of cortical interneurons (Gelman et al., 2009) but given that very few $\mathrm{CR}+$ interneurons derive from this zone, we will focus on the MGE and CGE.

Lineage analyses using either grafts or genetic tools such as Cre driver lines that label specifically a subfield of the GE have shown that parvalbumin-expressing $(\mathrm{PV}+)$ and $\mathrm{SOM}+$ interneurons are generated in the MGE at different time points (between E9 and E15, Figure 1; Xu et al., 2004; Butt et al., 2005; Miyoshi et al., 2007; Tricoire et al., 2011). In contrast, similar approaches revealed that a large portion of the remaining interneuron subtypes, including CR+ interneurons, derive from the CGE and are produced at later embryonic stages (between E12.5 and E16.5, Figure 1; Lee et al., 2010; Miyoshi et al., 2010; Tricoire et al., 2011). In addition to being generated by distinct progenitors, $\mathrm{CR}+$ interneuron precursors use a different migratory pathway. While $\mathrm{SOM}+$ interneurons take a more rostrolateral route, CGE-derived interneurons take a caudal path for their tangential migration (Kanatani et al., 2008). The late birth of CGE-derived interneurons has the consequence that they are still migrating at birth and reach their final destination later than MGE-derived interneurons (Miyoshi et al., 2010). However, several refinements have to be considered. SOM+ hippocampal neurons exhibit a dual origin with one expressing type 3 serotonin receptor (5-HT3 R) and the other not (Chittajallu et al., 2013). In the neocortex, such a dichotomy has not been reported yet.

Several transcription factors of $\mathrm{CR}+($ and SOM+) interneurons are necessary for the proper specification and migration from the GE. Mice lacking the Dlxl gene show reduction of $\mathrm{CR}+$ and $\mathrm{SOM}+$ interneurons without affecting the $\mathrm{PV}+$ population (Cobos et al., 2005). Removal of the transcription factor Nkx2.1 restricted at early embryonic stages to the MGE domain
(Figure 1) results in a molecular and cellular switch of MGEderived cortical interneurons ( $\mathrm{PV}+$ and $\mathrm{SOM}+$ subpopulations) to CGE-derived neurons (VIP+ and CR+ cells; Butt et al., 2008).

In contrast with SOM+ interneurons, little is known about the regional and cell type specification of CGE in general and of $\mathrm{CR}+$ bipolar interneurons in particular. Gsx2 (also called Gsh2) is enriched in (but not restricted to) the LGE and CGE from early development (Figure 1) and has been directly implicated in promoting the $\mathrm{CR}+$ interneuron identity (Xu et al., 2010a). The orphan nuclear receptor COUP-TFII shows restricted expression in the CGE (Kanatani et al., 2008; Willi-Monnerat et al., 2008) and, together with COUP-TFI, is required for the caudal migration of cortical interneurons (Tripodi et al., 2004). Moreover, in Nkx2.1 mutant mice, a higher number of CR+ and VIP+ cortical interneurons are generated and COUP-TFII is ectopically expressed in the MGE (Butt et al., 2008). Conversely, conditional loss-of-function of COUP-TFII in subventricular precursors and postmitotic cells leads to a decrease in VIP+ and CR+ interneurons, compensated by the concurrent increase of MGE-derived $\mathrm{PV}+$ interneurons. Interestingly, COUP-TFI mutants are more resistant to pharmacologically induced seizures (Lodato et al., 2011). In addition to these genetic factors, electrical activity has been also shown to regulate development of cortical neurons. $\mathrm{CR}+$ but not VIP+ interneurons activity is required before postnatal day 3 for correct migration and Elmo1, a target of Dlx1 and expressed in $\mathrm{CR}+$ neurons, is both necessary and sufficient for this activity-dependent interneuron migration (De Marco Garcia et al., 2011).

Over the past decade, many advances have been achieved in the identification of the genetic factors that influence the specification of cortical and hippocampal interneurons especially for MGE-derived interneurons. However, the program specifying the identity of CGE-derived interneurons still needs to be unraveled. For instance, the cues that regulate the final maturation of the morphological, synaptic and electrophysiological properties have to be determined. Indeed, although embryonic origin is a major contributing factor, immature interneurons arriving at their final destination are likely to encounter local factors such as guidance molecules and specific levels of network activity that will instruct them where to grow dendrites and axons.

\section{ANATOMICAL PROPERTIES LAMINAR, COLUMNAR, AND AREAL DISTRIBUTION PATTERN}

The initial descriptions of the brain-wide distribution of $\mathrm{CR}+$ neurons did not report obvious differences in the number or type of neurons across the different cortical areas (Jacobowitz and Winsky, 1991; Resibois and Rogers, 1992; Gabbott et al., 1997). They observed that within a certain cortical area always supragranular layers II/III show the highest density of CR+ neurons (Figure 2). A more fine-grained analysis, however, suggested that there is a subtle gradient from rostral to caudal, with a higher density of CR + neurons in the visual cortex (Xu et al., 2010b), a finding similar to that of VIP+ neurons, one of the major subtypes of CR+ neurons (Morrison et al., 1984; Rogers, 1992; Gonchar et al., 2008). Interestingly, in the mouse barrel cortex where columnar modules are easily visualized, both, CR+ and $\mathrm{VIP}+$ interneurons showed a preference for septal compartments 
A

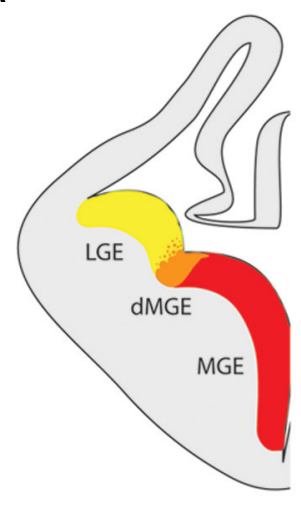

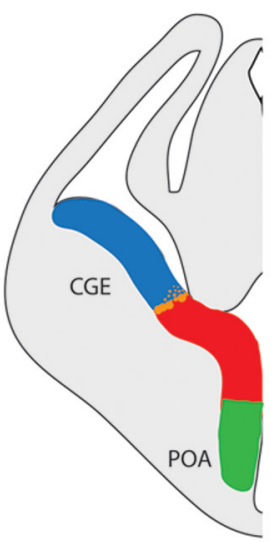

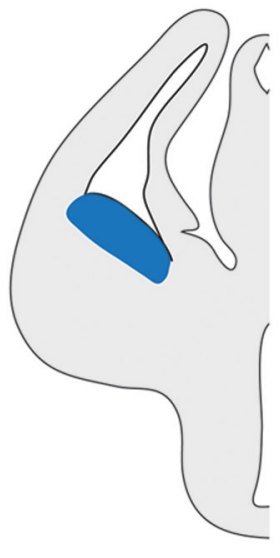

B

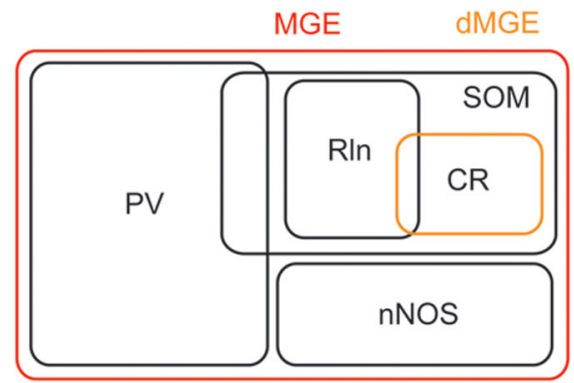

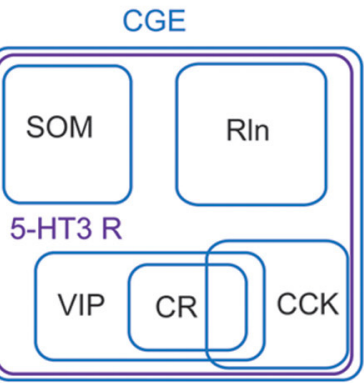

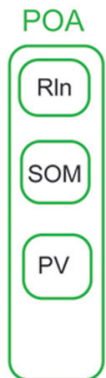

C

VZ

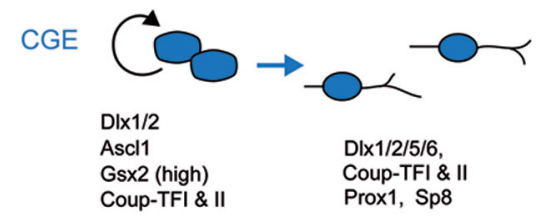

Cortical plate

Mature cortex
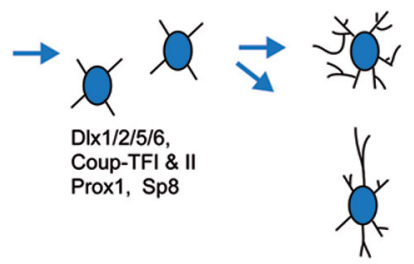

RI

DIx $1 / 2 / 5 / 6$

Coup-TFII

Prox1, Sp8

VIPICR

DIx1/2/5/6,

Coup-TFI \& 11
Prox 1 Sp8
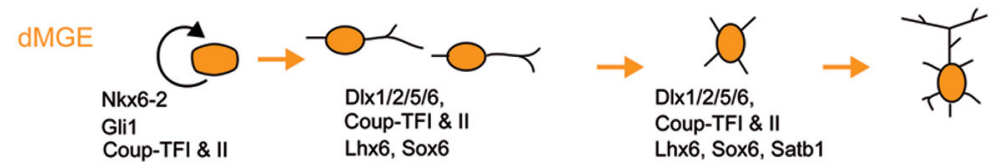

SST CR

DIx1/2/5/6,

Lhx6, Sox6, Satb1

Lhx6, Sox6, Satb1

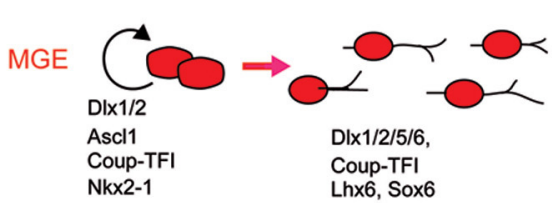

FIGURE 1 | Embryonic origins and genetic factors affecting the mature fate of cortical interneurons. (A) Diagram showing the subdivisions of the embryonic telencephalon. The three regions where cortical and hippocampal interneurons originate are the medial ganglionic eminence (MGE) (including the dorsal MGE-dMGE), the caudal ganglionic eminence (CGE), and the preoptic area (POA). The lateral ganglionic eminence (LGE) gives rise, amongst other, to basal forebrain neurons. (B) Ball scheme of the major classes of cortical and hippocampal interneurons identified using neurochemical markers and represented depending of their place of origin in the embryonic telencephalon. The MGE generates $50 \%$ of all cortical interneurons and includes mainly parvalbumin (PV)-expressing and

somatostatin (SOM)-expressing subtypes. In hippocampus, it also includes a large population expressing the neuronal isoform of nitric oxide synthase (nNOS). CGE-derived reelin (RIn)-expressing interneurons represent the neurogliaform cells. In both cortex and hippocampus, almost all CGE-derived interneurons express the type 3 serotonin receptor (5-HT3 R). In contrast with cortex, hippocampal SOM+ interneuron have a dual origin with a significant subset co-expressing 5-HT3 R. VIP; vasoactive intestinal polypeptide, CR, calretinin; CCK, cholecystokinin. (C) Genetic programs controlling neurogenesis, cell commitment, tangential, and radial migration and maturation of cortical interneuron. The subdivision of the neuroepithelium (Continued) 


\section{FIGURE 1 | Continued}

can be identified by combinatorial expression of transcription factors involved at different stages of cortical interneuron development. Some of these factors participate broadly in interneuron development such as Dlx and CoupTF gene families. Some transcription factors are unique to specific domains and/or stages of differentiation: Nkx2-1 defines the MGE and activates a cascade of genes including Lhx6, Sox6, and Satb1; Nkx6-2 and GLI1 are enriched in the dMGE. Prox1 and SP8 are expressed in CGE-derived cortical interneurons at all stages of their development (adapted from Kessaris et al., 2014).
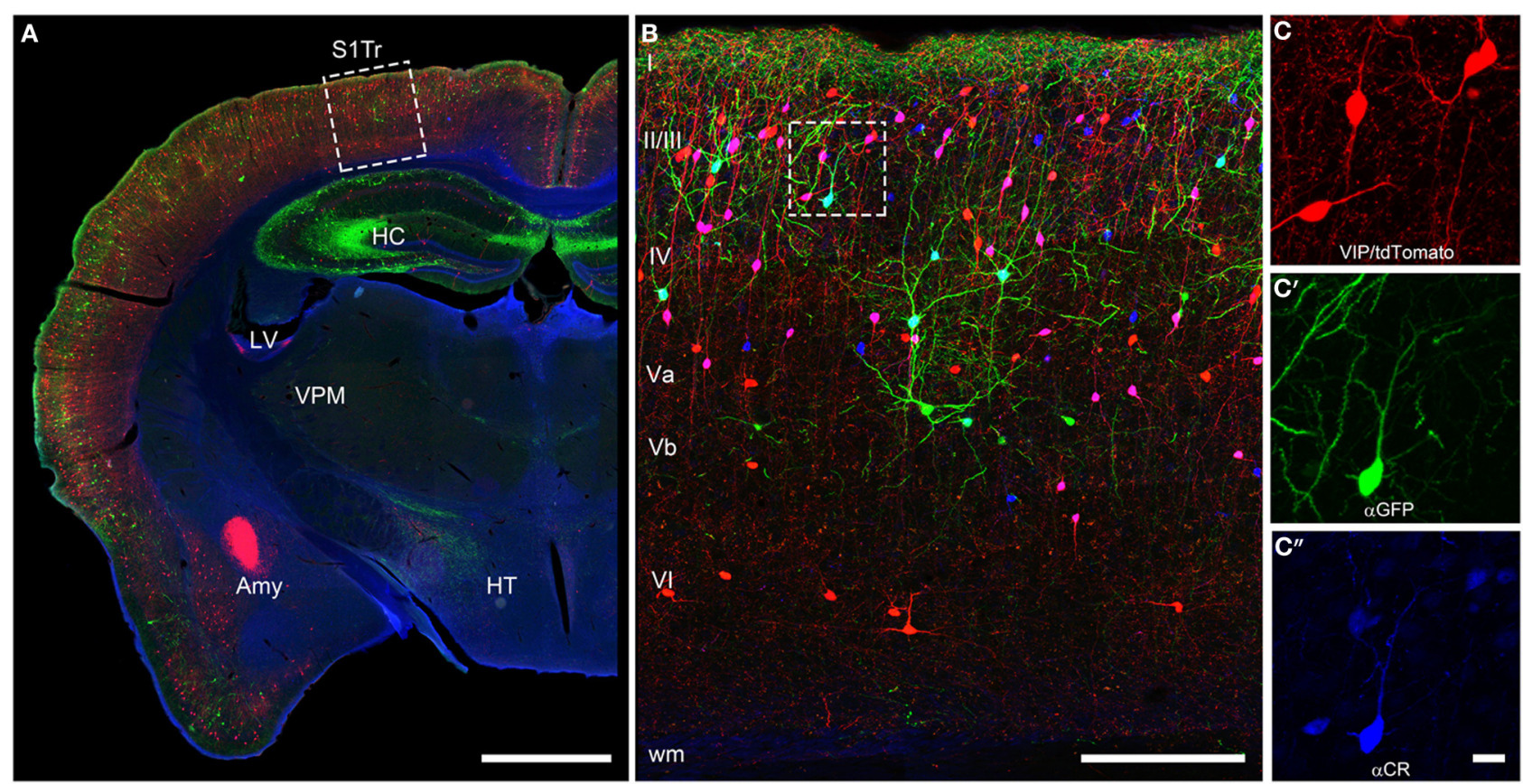

FIGURE 2 | Coronal brain section of a VIPcre/tdTomato/GIN mouse additionally stained for calretinin. Immunostaining of calretinin in a coronal brain section of a VIPcre/tdTomato/GIN mouse shows VIP neurons in red, Martinotti cells in green and calretinin in blue in the primary somatosensory cortex (S1Tr). (A) Low magnification of one hemisphere depicting the hippocampus $(\mathrm{HC})$, the lateral ventricle (LV), the amygdala (Amy), the thalamic nucleus ventralis posteromedialis (VPM), and the hypothalamus $(\mathrm{HT})$; the dashed rectangle marks the selected area of (B); scale bar: $1000 \mu \mathrm{m}$. (B) Close-up of the rectangle in (A) in a maximum intensity projection: Roman numerals indicate cortical layers: dashed rectangle marks the selected area of (C-C"); scale bar: $250 \mu \mathrm{m}$. Please note that VIP neurons co-localizing CR appear pink whereas Martinotti cells that co-localize CR show a cyan-colored soma. (C) Red channel of the inset in (B), showing the tdTomato signal only; ( $\mathbf{C}^{\prime}$ ) green channel of the inset in (B), showing the GFP only; (C') blue channel of the inset in (B), showing the labeled calretinin antibody only; scale bar for (C-C") $20 \mu \mathrm{m}$. Please not that nearly all VIP and the single Martinotti cell are co-localizing $\mathrm{CR}$. over barrel-associated columns (Zilles et al., 1993; Melvin and Dyck, 2003). Such a preference was not obvious for the rat barrel cortex (Bayraktar et al., 2000), although no tangential sections where used, which would have allowed a much better resolution of columnar compartments. In summary, CR+ neurons show a relatively uniform appearance across cortical areas in terms of distribution, numbers and cell types, suggesting that they perform a basic and comparable function in neuronal processing or control of energy supply.

\section{CELLULAR MORPHOLOGY}

Since the recognition of cortical interneurons as a distinct cell class different from principal (i.e., pyramidal) cells (Jones, 1975; Fairen et al., 1984; Ramón y Cajal, 1995), researchers have been struck by the abundance of morphological features that are already expressed at the somatodendritic level, let alone by the manifold axonal ramification patterns when they later became observable (DeFelipe et al., 2013). To agree upon a common nomenclature on the somatodendritic patterns of GABAergic

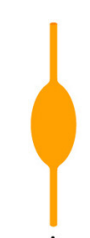

A
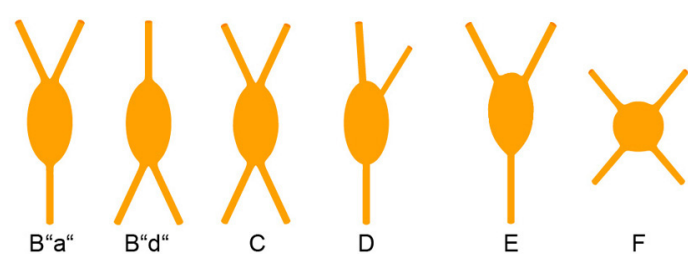

FIGURE 3 | Somatodendritic morphology of CR+ interneurons. For details see text. interneurons, a minimal consensus paper was published (Ascoli et al., 2008). However, we feel that for the appreciation of the full diversity of observable somatodendritic configurations, this terminology has to be extended and refined in the future. In the following, we will elaborate on what we originally proposed for VIP+ neurons in the rat barrel cortex (Bayraktar et al., 2000).

This classification is strictly focused on the origin of the primary dendrites at the soma (Figure 3). Specific 
examples in a histological preparation can be found in Figure 2 .

A. Bipolar: Two dendrites originating from opposite sides of a spindle (to round)-shaped soma. It is not important in this classification how close or far from the soma these dendrites starts to branch into their terminal tufts.

B. Single tufted: A single dendrite on one side of the soma and at least 2 dendrites originating individually from the opposite side. We suggest that acceptable origins from where a dendrite is allowed to emerge for the tufted category are $\pm 20^{\circ}$ from the upper or lower pole of the soma. (In case that there are dendritic origins outside these sectors, the neuron belongs to one of the following groups). This group can be further specified as "a" = tuft ascending and " $\mathrm{d}$ " = tuft descending.

C. Bitufted: Two dendritic tufts as defined above, originating from opposite sides of the soma.

D. Modified: Bipolar/single-tufted/bitufted: they possess a third dendrite originating anywhere else than the above defined circumference at the soma.

E. Tripolar: This is a difficult term since as such it can be a modified bipolar with a more or less extensive third dendrite (that should also be vertically oriented) or it can be the "smallest" form of a multipolar cell (which then can be oriented to any direction). Whenever this term is used, it should be specified to which of the more general categories of somatodendritic configuration (D or F) the cell is closer.

F. Multipolar: At least 4 (or 3, see above) dendrites originating from a round to polygonal soma.

G. Others: Any neuron that is so different and rare (i.e., horizontal) that it does not fit in the above categories.

With this in mind, we here shortly summarize that cortical $\mathrm{CR}+$ neurons, on the basis of their somatodendritic properties, were classified by different researchers as bipolar (Jacobowitz and Winsky, 1991; Kawaguchi and Kubota, 1996), bipolar and multipolar (Resibois and Rogers, 1992), or bipolar, bitufted, multipolar and horizontal (Caputi et al., 2009; Barinka and Druga, 2010), respectively. Unfortunately, not too many axonal reconstructions of these cells are available but it is assumed that the bipolar or bitufted dendritic trees are mostly accompanied by a vertical translaminar axonal arbor whereas the multipolar dendritic trees go along with a horizontal transcolumnar ramification of the axon (Caputi et al., 2009).

\section{NEUROCHEMICAL PROPERTIES: CO-EXPRESSION OF NEUROPEPTIDES AND CLASSICAL NEUROTRANSMITTERS}

The degree of co-expression of $\mathrm{CR}$ with other markers can strongly vary between species. For instance in rat, a large majority (70-90\%) of cortical CR+ cells exhibits VIP immunoreactivity (Rogers, 1992; Kubota et al., 1994) whereas this co-expression drops down to about 35\% in mouse (Gonchar et al., 2008; $\mathrm{Xu}$ et al., 2010b). This difference probably comes from the presence of a SOM+ neuronal subpopulation accounting for $30-40 \%$ of CR+ cells in mouse (Halabisky et al., 2006; Xu et al., 2006; Gonchar et al., 2008), which is virtually absent in rat (Rogers, 1992; Kubota et al., 1994, 2011; Gonchar and Burkhalter, 1997) and human (Gonzalez-Albo et al., 2001).
However, such a difference between species is not retrieved at the mRNA level since co-expression of CR and SOM transcripts has been observed using single cell RT-PCR both in mouse (Perrenoud et al., 2013) and rat in which the co-expression level is up to $40 \%$ of the CR+ cortical neurons (Cauli et al., 1997, 2000; Wang et al., 2004; Toledo-Rodriguez et al., 2005; Gallopin et al., 2006; Pohlkamp et al., 2013). The absence of co-immunodetection of CR and SOM in rat is probably due to a species-dependent post-transcriptional (Kwan et al., 2012) and/or a post-translational control (Herrero-Mendez et al., 2009). These observations indicate that CR-expressing bipolar cells, but not $\mathrm{CR}+/ \mathrm{SOM}+$ (often multipolar) cells, are a common cell type in rats and mice.

In addition to VIP (Rogers, 1992; Kubota et al., 1994; Halabisky et al., 2006; Xu et al., 2006; Gonchar et al., 2008), CR + bipolar interneurons co-express other neuropeptides (Figure 1). CRF and the preprotachykinin Neurokinin B (NKB), expressed in about one third of $\mathrm{CR}+$ bipolar neurons, are rather common neuropeptides in superficial layers (Kaneko et al., 1998; Gallopin et al., 2006; Kubota et al., 2011). Enkephalin, an endogeneous opioid, is also expressed in a subpopulation of CR+/VIP+ bipolar interneurons (Taki et al., 2000; Férézou et al., 2007). By contrast, despite its abundance in the cerebral cortex (Beinfeld et al., 1981) and its frequent co-expression with VIP (Cauli et al., 1997, 2000; Kubota and Kawaguchi, 1997; Férézou et al., 2002; Kubota et al., 2011), CCK is only expressed in a minority of CR+ neurons (Cauli et al., 1997; Kubota and Kawaguchi, 1997; Gallopin et al., 2006; Gonchar et al., 2008; Karagiannis et al., 2009; Kubota et al., 2011; Pohlkamp et al., 2013). In addition to neuropeptides, up to $50 \%$ of VIP+ bipolar neurons co-express choline acetyl-transferase (ChAT) (Eckenstein and Baughman, 1984; Peters and Harriman, 1988; Chédotal et al., 1994a; Bayraktar et al., 1997; Cauli et al., 1997; Porter et al., 1998; Von Engelhardt et al., 2007; Gonchar et al., 2008; Consonni et al., 2009). Although co-expression of GABA and ChAT has been demonstrated in CR+/VIP+ bipolar interneurons (Kosaka et al., 1988; Bayraktar et al., 1997; Cauli et al., 1997; Porter et al., 1998) (Figure 4), the cholinergic nature of bipolar neurons is species-dependent. Indeed, the vesicular acetylcholine transporter, an essential component of the cholinergic system, is expressed in cortical interneurons from rats but not from mice or humans (Schafer et al., 1994, 1995; Gilmor et al., 1996; Weihe et al., 1996; Bhagwandin et al., 2006). Expression of nitric oxide synthase (NOS) is very marginal in bipolar $\mathrm{CR}+/ \mathrm{VIP}+$ neurons and also appears to occur mainly in mouse (Lee and Jeon, 2005; Gonchar et al., 2008; Tricoire et al., 2010; Magno et al., 2012; Perrenoud et al., 2012a; Pohlkamp et al., 2013).

In summary, $\mathrm{CR}+/ \mathrm{VIP}+$ bipolar neurons express a large repertoire of neurotransmitters and neuromodulators indicative of their neurochemical diversity. This suggests that they are likely to play multiple roles in cortical physiology.

\section{ELECTROPHYSIOLOGICAL FEATURES}

A remarkable passive electrophysiological feature (Ascoli et al., 2008) of CR+/VIP+ bipolar neurons is their relatively high input resistance (Kawaguchi and Kubota, 1996; Cauli et al., 1997, 




FIGURE 4 | Single cell RT-PCR analysis of a rat CR+ interneuron. (A) Current-clamp recording obtained in response to a depolarizing current pulse $(300 \mathrm{pA})$. Note the initial burst followed by irregularly discharged action potentials. (B) Single-cell RT-PCR analysis of the same neuron revealing co-expression of CR, VIP, ChAT, GAD65, and GAD67. (C)

Comparison of the biocytin labeling of the recorded neuron (left panel) with the immunostaining of the slice with an antibody against CR (right panel). Note the immunoreactivity of the biocytin-labeled cell (scale bar $40 \mu \mathrm{m}$, adapted from Cauli et al., 1997). (D) Intracellular biocytin labeling of another CR+ bipolar cell analyzed by singe cell RT-PCR. This neuron had a vertically oriented dendritic arborization. Pial surface is upward (scale bar, $20 \mu \mathrm{m}$ ).

2000; Gallopin et al., 2006; Karagiannis et al., 2009; Lee et al., 2010; Vucurovic et al., 2010), contrasting sharply with the low input resistance of fast spiking PV+ neurons (Kawaguchi and Kubota, 1993; Okaty et al., 2009; Battaglia et al., 2013). This property allows CR+/VIP+ neurons to be substantially depolarized by the small excitatory synaptic currents they receive from thalamic inputs (Lee et al., 2010). The presence of a prominent $\mathrm{I}_{H}$ current in SOM+ neurons underlying their distinctive voltage sag induced by hyperpolarization partially explains the slightly lower input resistance and the more depolarized resting membrane potential of SOM+ interneurons compared with those of CR+/VIP+ bipolar neurons (Wang et al., 2004; Halabisky et al., 2006; Ma et al., 2006; Xu et al., 2006; Karagiannis et al., 2009). Alike SOM+ interneurons, VIP+ cells have been reported to exhibit the ability to discharge low-threshold spikes driven by $\mathrm{I}_{T}$ calcium channels (Kawaguchi and Kubota, 1996; Cauli et al., 1997; Porter et al., 1999; Wang et al., 2004). VIP+ bipolar interneurons displayed action potentials of a duration intermediate to those of fast spiking interneurons and pyramidal cells (Kawaguchi and Kubota, 1996; Cauli et al., 1997, 2000; Karagiannis et al., 2009). A complex repolarization phase of their action potentials consisting of a fast after-hyperpolarization (AHP), followed by an after-depolarization and a medium AHP has been frequently observed in both VIP+ and SOM+ interneurons (Wang et al., 2004; Fanselow et al., 2008; Karagiannis et al., 2009), VIP+, but also SOM+ interneurons, characteristically displayed a pronounced frequency adaptation (Kawaguchi and Kubota, 1996; Cauli et al., 1997, 2000; Wang et al., 2004; Halabisky et al., 2006; Ma et al., 2006; Xu et al., 2006) which can result in an irregular firing pattern (Figure 4) (Cauli et al., 1997, 2000; Wang et al., 2004) when a slowly inactivating $I_{D}$ potassium current is prominently present (Porter et al., 1998). Similarly to SOM+ interneurons, CR+ bipolar neurons exhibit backpropagating action potentials accompanied by an intracellular $\mathrm{Ca}^{2+}$ increase (Kaiser et al., 2001; Goldberg et al., 2003; Cho et al., 2010), which allows the release of neurotransmitters from dendrites as reported for SOM+ interneurons (Zilberter et al., 1999). Since the extent of action potential backpropagation is modulated by the presence of $\mathrm{I}_{A}$ potassium channels (Goldberg et al., 2003; Cho et al., 2010), this suggests that the dendritic release of CR+ bipolar interneurons (Figures 5, 6) can be finely tuned.

In summary, $\mathrm{CR}+$ bipolar interneurons largely display the electrophysiological features of adapting neurons (Ascoli et al., 2008). Their distinctive intrinsic electrophysiological properties indicate that they have specific integrative properties and therefore are likely to play specific roles in the physiology of cortical circuits, e.g., state-dependently remove the blanket of inhibition from principal neurons (Karnani et al., 2014).

\section{SYNAPTIC INPUTS \\ CORTICAL}

In general, our specific knowledge on connectivity is very restricted. Probably the most precise data for local synaptic inputs to $\mathrm{CR}+$ neurons come from paired recordings in layer II/III of the primary somatosensory cortex in a CR-BAC-transgenic mouse (Caputi et al., 2009). These authors reported that the two types of neurons that they defined as the major cellular components of the $\mathrm{CR}+$ neuronal population receive different types of inputs (and also form different types of output; see below). Bipolar $\mathrm{VIP}+/ \mathrm{CR}+$ interneurons (BCR) receive functionally depressing inputs from local pyramidal cells with a probability of $18.3 \%$, from fast-spiking interneurons (29.7\%), from multipolar $\mathrm{SOM}+/ \mathrm{CR}+$ interneurons (MCR; $41.1 \%$ ) as well as facilitating inputs from other BCR (31.8\%) (Figure 5). By contrast, MCR show facilitating inputs from pyramidal cells (17.4\%) and from BCR $(76.4 \%)$ as well as depressing inputs from fast-spiking cells 


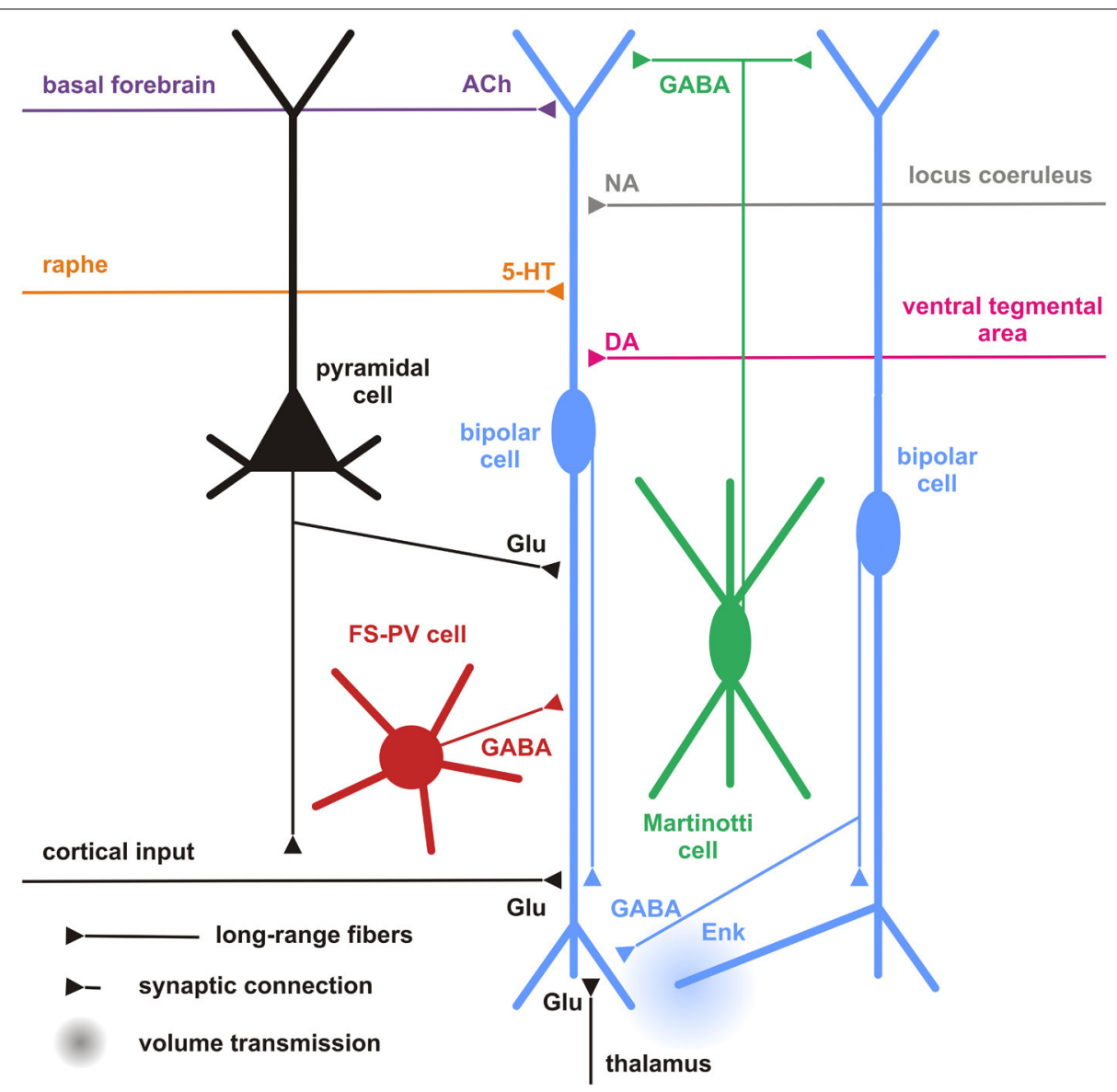

FIGURE 5 | Cortical and subcortical inputs of CR+ bipolar interneurons. Schematic representation summarizing the different local cortical neurons (colored cells) and the long-range cortical and subcortical axon terminals (colored fibers) targeting $\mathrm{CR}+$ bipolar interneurons (centered blue bipolar cell). Dendrites and axons are depicted by thick and thin lines, respectively. Anatomical synaptic connections are represented by triangles and putative volume transmission by spherical gradients. The local neuronal types targeting bipolar $\mathrm{CR}+$ and their respective neurotransmitters are schematized and color-coded; pyramidal cells (black, glutamate), fast spiking (FS)-PV neurons (red, GABA), Martinotti cells (green, GABA) other CR+ bipolar interneurons (blue, GABA and Enk [enkephalin]). Neurotransmitters of the long-range cortical and subcortical fibers are color-coded (Glu [glutamate; Black], 5-HT [serotonin, orange], ACh [acetylcholine, purple], NA [noradrenaline, gray], DA [dopamine, pink]) and their major origins indicated using the same color code.
(20\%) and other MCR (9.8\%). Interestingly, it appears that inputs to $\mathrm{CR}+/ \mathrm{VIP}+$ (BCR) neurons are mainly depressing (Porter et al., 1998; Rozov et al., 2001), whereas all their outputs are facilitating and, vice versa, for $\mathrm{CR}+/ \mathrm{SOM}+(\mathrm{MCR})$ neurons inputs are often facilitating whereas their outputs show a target cell type-specific variability (Caputi et al., 2009). These data do not agree well with paired recordings from rat barrel cortex, probably due to a mixture of species differences and less defined populations of bipolar vs. multipolar neurons in this study (Reyes et al., 1998).

Another rich source of observations describing the inputs to layer II/III CR+ neurons is provided by the glutamate uncaging studies in different transgenic mouse lines ( $\mathrm{Xu}$ and Callaway, 2009). They distinguished CR+ and CR- Martinotti cells and (putatively CR + and VIP+) bipolar cells. CR+ Martinotti cells (as all other types of inhibitory neurons in their study) received their strongest excitatory inputs within layer II/III whereas bipolar cells possessed a second strong origin of inputs located in layer IV.
Going beyond the local cortical circuits, Gonchar and Burkhalter also described long-range cortical inputs to $\mathrm{CR}+$ neurons (Figure 5) (Gonchar and Burkhalter, 2003). Here, tracer injections to label connections between primary (V1) and secondary (V2) visual areas disclosed a circuit motif where CR+ neurons (specifically in layer I) are involved in feedback inhibition from V2 to V1, whereas few if any such long range connections are found on layer II/III CR interneurons. In this layer, PV+ interneurons were the main recipients for feedback projections, as they were for V1 to V2-directed feedforward projections.

$\mathrm{CR}+$ bipolar interneurons may integrate these glutamatergic excitatory afferents by expressing ionotropic glutamate receptors of the AMPA subtype exhibiting a low $\mathrm{Ca}^{2+}$ permeability (Porter et al., 1998; Rozov et al., 2001) associated with high levels of the GluR2 subunit (Jonas et al., 1994). They, however, distinctly exhibit a low occurrence of GluR3 subunits and mainly express the flop variants of GluR subunits (Lambolez et al., 1996; Angulo et al., 1997; Porter et al., 1998; Cauli et al., 2000). GluR5 
and GluR6 are the main kainate receptor subunits expressed in CR+ bipolar neurons (Porter et al., 1998; Cauli et al., 2000). Similarly to other cortical interneurons, $\mathrm{CR}+$ bipolar interneurons express NR2A, B and D subunits of the NMDA receptor, the latter being found at very low levels in pyramidal cells (Flint et al., 1997; Porter et al., 1998; Cauli et al., 2000), indicating that bipolar interneurons can express very slowly inactivating NMDA receptors (Vicini et al., 1998). Similarly to SOM+ interneurons, the activity of $\mathrm{CR}+$ bipolar and can be also modulated by the group I metabotropic glutamate receptors mGluR1 and mGluR5 (Baude et al., 1993; Kerner et al., 1997; Cauli et al., 2000; van Hooft et al., 2000; Ferraguti et al., 2004). The group III metabotropic receptor mGluR7 expressed by CR+/VIP+ bipolar neurons (Cauli et al., 2000) is presynaptically localized onto synapses targeting SOM+ interneurons which suggests a glutamatergic control of disinhibition (Dalezios et al., 2002). In summary, CR+/VIP+ bipolar neurons exhibit a cell-type-specific expression pattern of glutamate receptors allowing them to integrate glutamatergic inputs with distinct temporal and spatial features (Figure 5).

In terms of their inhibitory inputs, alike SOM+ cells, CR+ bipolar interneurons sampled from layers II/III, IV, and V, which was quite uncommon for most other cell types studied ( $\mathrm{Xu}$ and Callaway, 2009). In their study, Gonchar and Burkhalter (1999) corroborated with morphological methods that rat $\mathrm{CR}+$ neurons in layer II/III do innervate each other with numerous GABAergic (symmetric) synapses on the soma as well as proximal and distal dendrites. In addition, many symmetric and asymmetric synapses that were not further identified by their specific origin could be found on the CR+ neurons. This is very similar to what we have described for VIP+ interneurons in rat barrel cortex (Staiger et al., 2004).

Since the expression of GABA receptor subunits by specific cortical neuronal subtypes is still poorly documented (Ruano et al., 1997; Olah et al., 2009) and given the diversity of these subunits (Laurie et al., 1992; Pirker et al., 2000), the specific GABA-A (but also GABA-B) receptor subunits of $\mathrm{CR}+$ bipolar interneurons remain largely undetermined.

Bipolar interneurons also possess receptors for intrinsic cortical neuromodulators including opioids and endocannabinoids. For instance, in the cerebral cortex $\mu$-opoid receptors are mainly expressed by bipolar interneurons which also produce enkephalin, its endogenous agonist (Taki et al., 2000). This autocrine/paracrine $\mu$-opoid transmission has been shown to restrict the inhibitory drive of $\mathrm{CR}+$ bipolar interneurons onto pyramidal cells (Férézou et al., 2007) (Figure 5). Similarly, the endocannabinoid transmission has been shown to exert a longlasting self-inhibition of putative SOM+ neurons (Bacci et al., 2004) by activation of CB1 receptors, which are broadly expressed by cortical neurons (Bodor et al., 2005; Hill et al., 2007). These two neuromodulatory systems, recruited during sustained firing, provide activity-dependent negative feedback to restrict the inhibitory actions of $\mathrm{CR}+$ interneurons.

In summary, $\mathrm{CR}+$ bipolar neurons possess a large integrative capability for excitatory as well as inhibitory inputs across different layers of a cortical column. A lot remains to be done to obtain a conclusive picture of the cortical input connectivity of
$\mathrm{CR}+$ bipolar neurons. However, already with the limited information available, it appears that these GABAergic interneurons do not only integrate excitatory and inhibitory inputs from local origin but that they also process long-range inputs from within the cortex and possibly subcortical sources (see next sections).

\section{SUBCORTICAL INPUTS Serotonergic}

Due to the paucity of specific studies on subcortical targeting of cortical bipolar $\mathrm{CR}+$ interneurons, inputs to the partially overlapping populations of VIP + as well as 5-HT3 $\mathrm{R}+$ interneurons might be considered here, too (Paspalas and Papadopoulos, 2001; Férézou et al., 2002; Cauli et al., 2004; Lee et al., 2010; Vucurovic et al., 2010; Rudy et al., 2011). The median raphe nucleus was found to be the subcortical region that gives rise to serotonergic input to $\mathrm{CR}+$ interneurons in rat hippocampus (Acsady et al., 1993). By using a bridge protein combined with retrograde viral tracers, the paramedian raphe was also found to project to a subpopulation of interneurons, which express ErbB4 in mouse primary somatosensory cortex (Choi and Callaway, 2011). Selectivity of the TVB-NRG1 bridge protein restricted the transfection to the subgroups of interneurons immunopositive for VIP and/or CR as well as ErbB4, including also small numbers of PV+/ErbB4 neurons but not SOM+ cells (Choi et al., 2010; Xu et al., 2010b).

Although the expression of the ionotropic 5-HT3 $\mathrm{R}$ is restricted to a subset of cortical interneurons, including $\mathrm{CR}+$ bipolar neurons and neurogliaform cells (Morales and Bloom, 1997; Férézou et al., 2002; Lee et al., 2010; Vucurovic et al., 2010), a subpopulation of hippocampal SOM+ O-LM cells originating from the CGE was recently found to be 5-HT3 R+ (Chittajallu et al., 2013). Cell-type-specific expression patterns of metabotropic 5-HT receptors are by far less documented. Nevertheless, 5-HT1a and 5-HT2a receptors are largely coexpressed in pyramidal cells and in a minority of interneurons positive for PV+ or CB+ (Aznar et al., 2003; Santana et al., 2004), suggesting that $\mathrm{CR}+$ bipolar interneurons barely express these receptors. Similarly, 5HT-2c R is not prominently expressed in $\mathrm{CR}+$ neurons of the rat medial prefrontal cortex (Liu et al., 2007). Given the reported segregation of 5-HT3 and 5-HT2a receptors in the monkey cerebral cortex (Jakab and Goldman-Rakic, 2000), it appears that 5-HT3 R is the major serotonin receptor expressed by $\mathrm{CR}+$ bipolar interneurons. These observations indicate that serotonergic raphe neurons can rapidly activate $\mathrm{CR}+$ bipolar interneurons as shown in the cerebral cortex (Férézou et al., 2002) (Figure 5).

Besides the paramedian raphe, additional origins of input were detected (with a decreasing probability) in the thalamus, secondary somatosensory, ipsilateral motor, retrosplenial, and contralateral primary somatosensory cortex as well as the nucleus basalis of Meynert (Choi et al., 2010; Xu et al., 2010b). Amongst the detected brain regions, the thalamus and basal nucleus of Meynert have been mostly investigated.

\section{Thalamic}

By anterograde tracing with PHA-L, neurons in the thalamus (mainly ventral posterior nucleus and lateral geniculate nucleus) 
were approved to form synaptic terminals onto the cortical VIP+ population of inhibitory interneurons (Staiger et al., 1996; Hajos et al., 1997). These anatomical observations were corroborated by functional evidence showing that 5 -HT3 $\mathrm{R}+$ interneurons receive monosynaptic thalamocortical inputs (Lee et al., 2010). By contrast, putative SOM+ interneurons were found to barely receive direct thalamic inputs (Beierlein et al., 2000, 2003).

\section{Cholinergic}

The projections from the basal nucleus of Meynert, where most of the cholinergic neurons projecting to the neocortex are located, are probably correlated to the nicotinic responsiveness of VIP+/5-HT3 R+ bipolar interneurons (Porter et al., 1999; Férézou et al., 2002, 2007; Lee et al., 2010; Arroyo et al., 2012; Fu et al., 2014). CR+/VIP+ bipolar neurons express functional highaffinity nicotinic receptors (Porter et al., 1999; Férézou et al., 2002, 2007; Gulledge et al., 2006; Lee et al., 2010; Arroyo et al., 2012; Fu et al., 2014) composed of $\alpha 4 \beta 2$ subunits and to a lesser extent $\alpha 5$ subunit, a composition which is developmentally regulated (Winzer-Serhan and Leslie, 2005). Alike SOM+ interneurons, $\mathrm{VIP}+$ bipolar neurons are depolarized by muscarinic agonists (Kawaguchi, 1997; Fanselow et al., 2008). Expression of $\mathrm{m} 2$ receptors has been reported in a minority $\mathrm{CR}+$ interneurons of the rat entorhinal cortex (Chaudhuri et al., 2005) but the subtypespecific identity of the muscarinic receptors inducing the depolarization of VIP+ bipolar interneurons remains unknown. This indicates that $\mathrm{CR}+$ interneurons integrate cholinergic afferences from the basal forebrain (Figure 5) as recently shown for ChAT+ bipolar interneurons using optogenetics (Arroyo et al., 2012), which might be important for behavioral state-dependent control of cortical circuits (Pi et al., 2013).

\section{Noradrenergic}

About 20\% of VIP+ interneurons are contacted by noradrenergic fibers (Figure 5), however, often with only a single symmetric synapse (Paspalas and Papadopoulos, 1998, 1999; Toussay et al., 2013). Despite the described expression of $\alpha$ - and $\beta$ adrenoreceptors in the cerebral cortex (Nicholas et al., 1993a,b; Pieribone et al., 1994; Scheinin et al., 1994; Venkatesan et al., 1996) and reported excitatory effects of $\alpha$-adrenoreceptors in hippocampal and cortical interneurons (Bergles et al., 1996; Marek and Aghajanian, 1996; Kawaguchi and Shindou, 1998), the expression of adrenoreceptors in CR+ interneurons has not been specifically investigated. However, inhibitory effects of $\alpha$ adrenoreceptors have been observed in discrete subpopulations of CCK+ and SOM+ interneurons (Kawaguchi and Shindou, 1998), whether or not this inhibitory effect of $\alpha$-adrenoreceptors is existent in $\mathrm{CR}+$ bipolar interneurons remains unknown. $\beta 1$ and $\beta 2$-adrenoreceptors are not as frequently expressed in $\mathrm{CR}+$ interneurons as compared to other types of interneurons (Liu et al., 2014).

\section{Dopaminergic}

Dopaminergic terminals have been shown to target interneurons (Sesack et al., 1995b), specifically CR+ interneurons in monkey prefrontal cortex (Sesack et al., 1995a) (Figure 5). However, there is no clear segregation in the expression profiles of dopamine receptors, which are frequently observed in pyramidal cells and interneurons of rodent and primate cortex with substantial coexpression (Vincent et al., 1993; Khan et al., 1998, 2000; Ciliax et al., 2000; Wedzony et al., 2000; Rivera et al., 2008; Oda et al., 2010). Nevertheless, regarding the expression of D1-like receptors, D1 receptors predominate in $\mathrm{PV}+$ interneurons of the primate prefrontal cortex whereas it is D5 in CR+ interneurons (Glausier et al., 2009).

At the moment, all that can be stated with certainty is that a lot of work is still needed to get a better idea how cortical $\mathrm{CR}+$ bipolar interneurons are influenced by subcortical sensory or modulatory inputs (Figure 5), which receptors are involved and how this modulation specifically affects sensory information processing or more general brain-state activity.

\section{TARGETS AND FUNCTIONS CORTICAL CIRCUIT \\ Neuronal targets}

Hippocampal $\mathrm{CR}+$ interneurons are considered to be interneuron-specific interneurons (Klausberger and Somogyi, 2008), which preferentially or even exclusively target other interneurons, presumably on their dendritic shafts. In rat hippocampus, post-embedding immunogold studies showed that most of the targets of $\mathrm{CR}+$ and VIP+ boutons (which might be derived from the same bipolar neurons co-localizing CR and VIP) were GABAergic dendrites (Acsady et al., 1996a; Gulyas et al., 1996). In the neocortex, the GABAergic dendrite targeting property of $\mathrm{CR}+$ or $\mathrm{VIP}+$ interneurons is more complex when taking cortical areas and layers into account. In monkey and rat visual cortex, differential modes of innervation by $\mathrm{CR}+$ interneurons exist in different layers. In layers I-III, $\mathrm{CR}+$ interneurons tended to synapse on dendritic shafts of other not further specified GABAergic interneurons. However, in layers IV-VI, GABA-negative spines belonging to pyramidal neurons were primarily innervated (Meskenaite, 1997; Gonchar and Burkhalter, 1999).

Paired recordings in layer II/III of the primary somatosensory cortex of CR-BAC-transgenic mice (Caputi et al., 2009) gave an idea of the functional output of these CR neurons. Bipolar CR+ (BCR) innervate pyramidal cells $(11.6 \%)$, fast-spiking interneurons $(29.7 \%)$, other BCR $(31.8 \%)$ and as already mentioned, preferably MCR (76.4\%). It is remarkable that the input with the highest probability in this study represents indirect evidence for the recently disclosed disinhibitory circuit from VIP neurons to Martinotti cells (Figure 6), for which several direct (Lee et al., 2013; Pfeffer et al., 2013; Pi et al., 2013; Fu et al., 2014) and indirect (Staiger et al., 2004; Gentet et al., 2012) lines of evidence are now available.

It has been shown in both, hippocampus and somatosensory cortex of rodents, that calbindin-expressing $(\mathrm{CB}+)$ interneurons are the targets of $\mathrm{CR}+$ or VIP+ interneurons (Acsady et al., 1996b; Gulyas et al., 1996; Staiger et al., 2004). CB+ interneurons form a heterogeneous population and can coexpress other neuropeptides or other calcium binding proteins, thus, it is reasonable to further differentiate $\mathrm{CB}+$ interneurons in order to distinguish the CR+ or VIP+ outputs to specific sets of interneurons. The most likely contacts are made with 


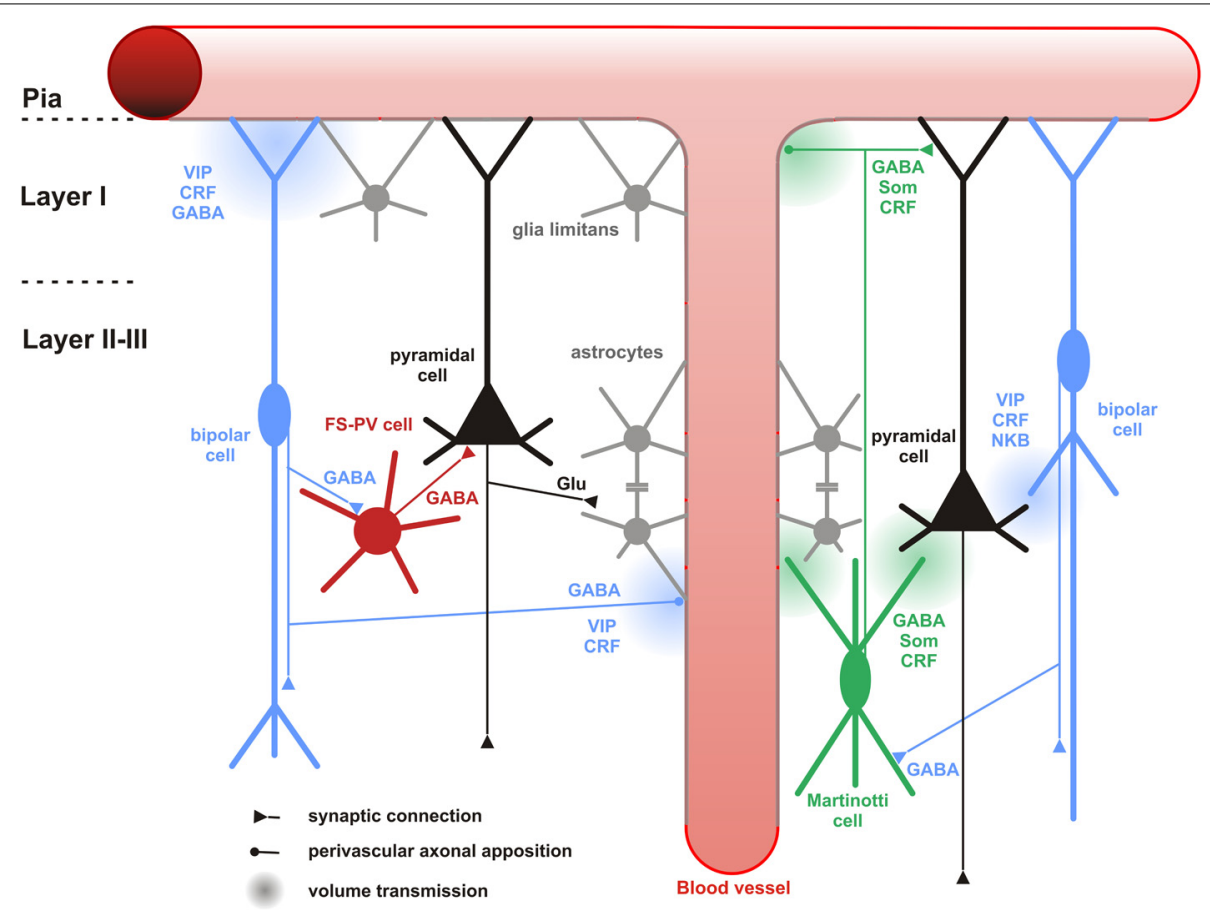

FIGURE 6 | Neuronal and non-neuronal targets of CR+ bipolar cells. Schematic representation summarizing the different neuronal and non-neuronal targets of $\mathrm{CR}+$ bipolar interneurons (blue neurons) and Martinotti cells (green neuron). Dendrites and axons are depicted by thick and thin lines, respectively. Anatomical synaptic connections are represented by triangles, axonal perivascular appositions by dots and putative volume transmission by spherical gradients. The cell types targeted by $\mathrm{CR}+$ neurons are schematized and color-coded; FS-PV neurons (red), Martinotti cells (green), pyramidal cells (black), glial cells (gray).
Astro-glial coverage of blood vessels is illustrated by a gray-colored abluminal side. The specific action of the multiple neurotransmitters released by $\mathrm{CR}+$ neurons is depicted by their location near the specific target and their origin color-coded (bipolar cell, blue; Martinotti cells, green). VIP, vasoactive intestinal polypeptide; CRF, corticotrophin releasing factor; NKB, neurokinin B; Som, somatostatin. The disinhibitory action of bipolar cells is represented by disynaptic circuits involving a bipolar interneuron, an intermediary interneuron (left: FS-PV cell; right: Som-Martinotti cell) and a pyramidal cell, respectively.
Martinotti cells which coexpress the markers CB and SOM (Kawaguchi and Kubota, 1996; Wang et al., 2004). Supporting this possible connection, recent functional studies described that in mouse somatosensory, visual, auditory, and prefrontal cortex, SOM+ interneurons were preferentially innervated by local VIP+ interneurons (Lee et al., 2013; Pfeffer et al., 2013; Pi et al., 2013). Because of the diversity of VIP+ and SOM+ neuronal subgroups, it would be important to know what exact types in terms of morphology contribute to this microcircuit. Some indirect evidence already exists. Bipolar $\mathrm{CR}+$ interneurons (BCRs) were immunopositive for VIP while multipolar CR+ interneurons (MCRs) were not (Caputi et al., 2009) and subgroups of SOM+ interneurons coexpressing CR with up to $95 \%$ or more than $50 \%$ were found in mouse visual and somatosensory cortex layers I-III, respectively (Xu et al., 2006). Therefore, it is hypothesized that BCRs, which are presumably CR+/VIP+ bipolar interneurons, target MCRs, which are probably $\mathrm{CR}+/ \mathrm{SOM}+$ Martinotti interneurons.

Beside Martinotti interneurons, subgroups of basket cells such as large basket cells and nest basket cells could be immunopositive for $\mathrm{CB}$, however, it is much more likely that these co-localize PV and not SOM (Wang et al., 2002). Two anatomical studies showed that VIP+ interneurons innervated PV+ interneurons, although it is debated whether there exists a preferential targeting in terms of putative PV+ subgroups (Dávid et al., 2007; Hioki et al., 2013). Behavioral experiments on mouse auditory and prefrontal cortex found that next to SOM+ interneurons, $\mathrm{PV}+$ interneurons were the second major outputs of VIP+ interneurons (Pi et al., 2013) (Figure 6), lending further support to a functional role of the above mentioned anatomical connections. In summary, the $\mathrm{CR}+$ bipolar interneurons seem to preferentially but not exclusively target other GABAergic interneurons, the molecular and anatomical properties of which need to be better analyzed.

\section{Neuronal processing}

The input-output connectivity pattern described above (Cortical and Neuronal targets) implies that bipolar CR+ interneurons do participate in disinhibitory but also feedforward and feed-back inhibitory circuits (Isaacson and Scanziani, 2011) of any cortical layer, column and area, especially when considering their high degree of colocalization with VIP (Porter et al., 1998; Reyes et al., 1998; Gonchar and Burkhalter, 2003; Caputi et al., 2009; Lee et al., 2013; Pfeffer et al., 2013; Pi et al., 2013). Whether the content of CR in these circuits is meaningful on its own, like it has recently been suggested for another calcium-binding protein (i.e., parvalbumin in the hippocampus; Donato et al., 2013), is currently unknown (but see Schwaller, 2014 for a recent review). The best understood function is now the disinhibitory action 
that is dependent on a unique circuit motif, i.e., targeting of other inhibitory interneurons, mostly SOM- (or CB-)expressing Martinotti cells. In the somatosensory system of mice, Lee et al. (2013) found that a specific projection from the whisker motor cortex excites VIP+ neurons and subsequently inhibits SOM+ neurons in the primary somatosensory cortex. This leads to a disinhibition of the apical dendrites of the pyramidal cells during exploratory behavior (Figure 6), probably acting as a "gateopener" for the paralemniscal pathway (Gentet et al., 2012). A similar gate-opening mechanism might be functional in the primary auditory cortex, when animals learn to associate a tone stimulus with an aversive context (Pi et al., 2013).

\section{Peptidergic neuromodulation}

The expression of numerous neuropeptides in $\mathrm{CR}+$ bipolar interneurons (Kubota et al., 1994, 2011; Kaneko et al., 1998; Taki et al., 2000), whose release requires a high level of neuronal activity (Zupanc, 1996; Baraban and Tallent, 2004), could also allow an activity-dependent fine tuning of the cortical network. For instance in the cat visual cortex, exogenously applied VIP had little or no effect on recorded neurons in the absence of visual stimulation, but enhanced their visual responses (Murphy et al., 1993; Fu et al., 2014). Consistently, by activating VPAC1 receptors and cAMP/PKA signaling, VIP reduced the slow AHP current and the tonic potassium current which regulates the excitability of hippocampal and cortical pyramidal neurons (Haug and Storm, 2000; Hu et al., 2011). Interestingly, CRF whose CRF1 receptors are also expressed by pyramidal neurons (Gallopin et al., 2006), induced an even more pronounced increase in cAMP/PKA signaling and modulation of potassium currents than VIP (Haug and Storm, 2000; Hu et al., 2011). Presumably because of the rapid desensitization of CRF1 receptors (Hauger et al., 2000), the action of CRF rapidly declined.

$\mathrm{CR}+$ bipolar interneurons are also likely to enhance glutamatergic activity via NKB signaling (Figure 6). Indeed, NK-3 receptor, the most selective receptor for NKB (Shigemoto et al., 1990), is expressed by layer V pyramidal cells (Ding et al., 1996; Shughrue et al., 1996; Gallopin et al., 2006) and its activation depolarizes them (Stacey et al., 2002; Rekling, 2004; Gallopin et al., 2006).

In summary, to be operational, this complex peptidergic neuromodulation of the cortical circuit (Figure 6) requires a selective enhancement of CR+ bipolar neurons activity to achieve a substantial release of neuropeptides (Zupanc, 1996; Baraban and Tallent, 2004). This prerequisite could be met during specific brain states such as locomotion (Fu et al., 2014), which associates an increased activity of basal forebrain cholinergic neurons (Lee et al., 2005) and serotonergic neurons of the raphe (Wu et al., 2004) leading to the concomitant activation of excitatory receptors on $\mathrm{CR}+$ bipolar neurons (see Subcortical inputs).

\section{GLIO-VASCULAR NETWORK}

\section{Non-neuronal targets}

Only very few studies have investigated the association of $\mathrm{CR}+$ interneurons with non-neuronal elements (Consonni et al., 2009). However, perivascular appositions of intrinsic cortical $\mathrm{VIP}+$ and ChAT + neurons, two markers frequently coexpressed in CR+ bipolar interneurons (Figure 4), are well documented in the rat cerebral cortex (Eckenstein and Baughman, 1984; Galea et al., 1991; Chédotal et al., 1994a,b; Paspalas and Papadopoulos, 1998; Fahrenkrug et al., 2000; Cauli et al., 2004). Different vascular compartments including pial and diving arterioles as well as capillaries are targeted by these terminals (Figure 6), which can be of conventional axonal or more unconventional dendritic origins. The precise examination of these perivascular appositions at the ultrastructural level revealed that VIP+ and ChAT+ varicosities are enriched in the vicinity of the vascular wall but systematically being separated from it by a thin astrocytic leaflet (Figure 6)(Chédotal et al., 1994a,b; Paspalas and Papadopoulos, 1998). These anatomical observations suggest that CR+ bipolar interneurons through glial and vascular interactions are likely to play a role in the control of cortical energy supply (see below).

\section{Neurovascular coupling}

VIP is a potent vasodilatory neuropeptide of pial and diving cortical arterioles (Wei et al., 1980; Itakura et al., 1987; Yaksh et al., 1987; Cauli et al., 2004) and the expression of VPAC1 receptors has been described in blood vessels (Martin et al., 1992; Fahrenkrug et al., 2000; Cauli et al., 2004). Furthermore, acetylcholine, but also GABA, induce vasodilatation of cerebral arterioles (Lee et al., 1984; Fergus and Lee, 1997). Numerous studies have reported an intimate association between VIP+/ChAT+ terminals of bipolar interneurons with cortical blood vessels (Eckenstein and Baughman, 1984; Galea et al., 1991; Chédotal et al., 1994a,b; Paspalas and Papadopoulos, 1998; Fahrenkrug et al., 2000; Cauli et al., 2004) (see Non-neuronal targets). Based on these observations, as early as in the 1980s and until recently, $\mathrm{VIP}+$ bipolar neurons have been proposed to be involved in the control of regional cerebral blood flow (Eckenstein and Baughman, 1984; Magistretti, 1990; Buzsaki et al., 2007; Cauli and Hamel, 2010). Although, single cell stimulation of VIP+ bipolar neurons was sufficient to elicit vasodilatation of nearby diving arterioles, the messengers recruited in these vascular responses were undetermined (Cauli et al., 2004). Indeed, the contribution of endogenous VIP to the control of regional cerebral blood flow has been largely restricted by the lack of selective VIP receptors antagonists (Yaksh et al., 1987). The role of VIP in neurovascular coupling was recently questioned in studies showing that vascular responses induced by sensory or pharmacological stimuli efficiently activating VIP+/ChAT+ bipolar neurons were insensitive to VIP receptors blockade (Lecrux et al., 2011; Perrenoud et al., 2012b). It also is unlikely that acetylcholine released by $\mathrm{VIP}+/ \mathrm{ChAT}+$ bipolar interneurons significantly contributes to the neurovascular coupling induced by sensory stimulation as these responses were insensitive to the blockade of muscarinic receptors (Lecrux et al., 2011) known to be involved in the vasodilatations induced by acetylcholine (Elhusseiny and Hamel, 2000; Kocharyan et al., 2008). GABA is another possible vasoactive messenger produced by bipolar interneurons since the activation of GABA-A receptors can indeed elicit vasodilation (Fergus and Lee, 1997) and their blockade impairs the neurovascular response to sensory stimulation (Lecrux et al., 2011). However, it is difficult to discriminate between a pure vascular effect of GABA from an alteration of the cortical network activity (Figure 6). 
CRF is another putative candidate peptide for neurovascular regulation through its release from $\mathrm{CR}+$ bipolar cells (Cauli and Hamel, 2010) (Figure 6). It is a vasodilator of blood vessels (De Michele et al., 2005) and its CRF1 receptors are expressed in blood vessel (Chalmers et al., 1995). To our knowledge, the contribution of CRF in neurovascular coupling has not been investigated and it may represent one of the yet undetermined vasodilatory messengers in the neurovascular response (Leithner et al., 2010; Liu et al., 2012). Interestingly, CRF is also expressed in a subpopulation of SOM+ interneurons (Gallopin et al., 2006; Kubota et al., 2011) but both SOM (Long et al., 1992) and the direct stimulation of SOM+ interneurons were shown to induce vasoconstrictions (Cauli et al., 2004). Given that SOM+ neurons are a major neuronal target of CR+ bipolar interneurons (see chapter 6.1.1), it is likely that CR+/VIP+ bipolar interneurons and $\mathrm{CR}+/ \mathrm{SOM}+$ interneurons (Figure 6), via vascular and/or synaptic interactions, play opposite roles in the control of regional cerebral blood flow (Kleinfeld et al., 2011).

\section{Neurometabolic coupling and gliotransmision}

The axonal and dendritic terminals of VIP+/ChAT + bipolar neurons, enriched in the vicinity of blood vessels, are physically separated from the vascular wall by a thin astrocytic leaflet (Figure 6), as already mentioned above (Chédotal et al., 1994a,b). Since astrocytes express VIP receptors (Martin et al., 1992), this suggests that bipolar interneurons may also activate astrocytic functions.

It is well established that astrocytes play a key role in cerebral metabolism, notably by storing blood glucose into glycogen (Cataldo and Broadwell, 1986; Magistretti, 1990; Allaman et al., 2011) but also by stimulating glycolysis and lactate release during neuronal activity (Pellerin and Magistretti, 1994; Ruminot et al., 2011; Choi et al., 2012), with lactate being a major oxidative energy substrate over glucose for neurons (Bouzier-Sore et al., 2003). Besides its role in energy metabolism astrocyte glucose is also the precursor of several gliotransmitters such as D-serine (Ehmsen et al., 2013) and possibly lactate (Barros, 2013) which play a key role in synaptic plasticity and memory formation (Panatier et al., 2006; Suzuki et al., 2011).

Interestingly, VIP, but not GABA, cholinergic agonists, somatostatin, CRF, or enkephalins, were shown to stimulate glycogenolysis in cortical slices (Magistretti et al., 1981, 1984; Magistretti, 1990). This indicates that VIP+/ChAT + bipolar interneurons can specifically enhance the recruitment of astrocytic glycogen stores (Figure 6) via VIP receptors (Martin et al., 1992) and cAMP/PKA signaling (Magistretti and Schorderet, 1984). In addition to this short term effect occurring within minutes, VIP also transcriptionally promotes glycogen re-synthesis within hours (Sorg and Magistretti, 1992). By tightly regulating glycogen content, and therefore astrocytes, glucose metabolism VIP+ bipolar neurons might play essential roles in the regulation of energy metabolism but also memory (Buzsaki et al., 2007; Pi et al., 2013).

\section{CONCLUSIONS}

More than 25 years ago, bipolar cells were considered to be enigmatic due to their rare occurrence, unusual synaptology, and unknown functions (Peters and Harriman, 1988). A big step forward in specifically studying the properties and functions of cortical inhibitory interneurons was the generation of specific mouse lines, first BAC-transgenics (Caputi et al., 2009), later Cre-driver lines (Taniguchi et al., 2011). The latter can be used now together with other exciting new methods, to precisely determine their inputs (via cre-dependent Rabies virus tracing; Choi et al., 2010; Fu et al., 2014) or outputs (via Cre-dependent channelrhodopsin-expressing vectors; Yizhar et al., 2011), both, in vivo and in vitro.

Eagerly awaiting these studies that will provide direct evidence for the functions of $\mathrm{CR}+$ bipolar interneurons, summarizing the available -mostly indirect evidence coming from studies on VIP Cre interneurons that are likely to co-express CR- one can state that probably the bipolar neurons are amongst the most complex cells in the cerebral cortex because they seem to be involved in every major mechanism that has to be active to support successful neuronal computation. At a supportive level, they play a core role in controlling blood flow and energy metabolism, using a multitude of effector molecules and associated receptors. At a neuronal level, it seems that they are able to integrate local and distant cortical excitatory inputs, together with subcortical sensory and modulatory inputs from all major neurochemical systems that regulate functions like arousal, attention, reward, and sleepwake cycles, to name but a few. All these inputs are integrated and conveyed as a processed output to the still badly characterized target neurons. However, assuming that $\mathrm{CR}+$ interneurons share most of their properties with VIP+ interneurons, the now well-established "disinhibitory circuit motif" might be the core function of this neuron class. This function was so tightly connected to several behavioral correlates that the notion came up that inhibitory interneurons are not only "modulators" of the information processing by pyramidal cell circuits but do compute information themselves (Hangya et al., 2014; Karnani et al., 2014; Munoz and Rudy, 2014).

With all this new information in mind, we think it is safe to conclude that cortical inhibitory bipolar interneurons are not that enigmatic anymore as they appeared roughly 25 years ago.

\section{ACKNOWLEDGMENTS}

The authors would like to apologize to all colleagues whose relevant studies could not be featured here due to the focus on calretinin neurons in the rodent neocortex of this article. The authors would like to thank Alvar Prönneke, Bianca Scheuer, Anastassios Karagiannis, and Csaba Dávid for contributions to figures in this review. Part of the work described here is derived from original studies funded by the German Research Council (DFG grants Sta 431/8-1, 10-1). Bruno Cauli and Xavier Toussay are supported by the Agence Nationale pour la Recherche (grant ANR-2011-MALZ-003-01).

\section{REFERENCES}

Acsady, L., Arabadzisz, D., and Freund, T. F. (1996a). Correlated morphological and neurochemical features identify different subsets of vasoactive intestinal polypeptide-immunoreactive interneurons in rat hippocampus. Neuroscience 73, 299-315. doi: 10.1016/0306-4522(95)00610-9

Acsady, L., Gorcs, T. J., and Freund, T. F. (1996b). Different populations of vasoactive intestinal polypeptide- immunoreactive interneurons are specialized to 
control pyramidal cells or interneurons in the hippocampus. Neuroscience 73 , 317-334. doi: 10.1016/0306-4522(95)00609-5

Acsady, L., Halasy, K., and Freund, T. F. (1993). Calretinin is present in nonpyramidal cells of the rat hippocampus-III. Their inputs from the median raphe and medial septal nuclei. Neuroscience 52, 829-841. doi: 10.1016/03064522(93)90532-K

Allaman, I., Belanger, M., and Magistretti, P. J. (2011). Astrocyte-neuron metabolic relationships, for better and for worse. Trends Neurosci. 34, 76-87. doi: 10.1016/j.tins.2010.12.001

Angulo, M. C., Lambolez, B., Audinat, E., Hestrin, S., and Rossier, J. (1997). Subunit composition, kinetic, and permeation properties of AMPA receptors in single neocortical nonpyramidal cells. J. Neurosci. 17, 6685-6696.

Arroyo, S., Bennett, C., Aziz, D., Brown, S. P., and Hestrin, S. (2012). Prolonged disynaptic inhibition in the cortex mediated by slow, non-alpha7 nicotinic excitation of a specific subset of cortical interneurons. J. Neurosci. 32, 3859-3864. doi: 10.1523/JNEUROSCI.0115-12.2012

Ascoli, A., Alonso-Nanclares, Z., Anderson, S. A., Barrionuevo, G., Avides-Piccione, R., Burkhalter, A., et al. (2008). Petilla terminology: nomenclature of features of GABAergic interneurons of the cerebral cortex. Nat. Rev. Neurosci. 9, 557-568. doi: $10.1038 / \mathrm{nrn} 2402$

Aznar, S., Qian, Z., Shah, R., Rahbek, B., and Knudsen, G. M. (2003). The 5-HT1A serotonin receptor is located on calbindin- and parvalbumincontaining neurons in the rat brain. Brain Res. 959, 58-67. doi: 10.1016/S00068993(02)03727-7

Bacci, A., Huguenard, J. R., and Prince, D. A. (2004). Long-lasting self-inhibition of neocortical interneurons mediated by endocannabinoids. Nature 431, 312-316. doi: 10.1038/nature02913

Baraban, S. C., and Tallent, M. K. (2004). Interneuron Diversity series: Interneuronal neuropeptides-endogenous regulators of neuronal excitability. Trends Neurosci. 27, 135-142. doi: 10.1016/j.tins.2004.01.008

Barinka, F., and Druga, R. (2010). Calretinin expression in the mammalian neocortex: a review. Physiol. Res. 59, 665-677.

Barros, L. F. (2013). Metabolic signaling by lactate in the brain. Trends Neurosci. 36, 396-404. doi: 10.1016/j.tins.2013.04.002

Bartolini, G., Ciceri, G., and Marin, O. (2013). Integration of GABAergic interneurons into cortical cell assemblies: lessons from embryos and adults. Neuron 79, 849-864. doi: 10.1016/j.neuron.2013.08.014

Batista-Brito, R., and Fishell, G. (2009). The developmental integration of cortical interneurons into a functional network. Curr. Top. Dev. Biol. 87, 81-118. doi: 10.1016/S0070-2153(09)01203-4

Battaglia, D., Karagiannis, A., Gallopin, T., Gutch, H. W., and Cauli, B. (2013). Beyond the frontiers of neuronal types. Front. Neural Circuits 7:13. doi: 10.3389/fncir.2013.00013

Baude, A., Nusser, Z., Roberts, J. D., Mulvihill, E., McIlhinney, R. A., and Somogyi, P. (1993). The metabotropic glutamate receptor (mGluR1 alpha) is concentrated at perisynaptic membrane of neuronal subpopulations as detected by immunogold reaction. Neuron 11, 771-787. doi: 10.1016/0896-6273(93) 90086-7

Bayraktar, T., Staiger, J. F., Acsady, L., Cozzari, C., Freund, T. F., and Zilles, K. (1997). Co-localization of vasoactive intestinal polypeptide, gammaaminobutyric acid and choline acetyltransferase in neocortical interneurons of the adult rat. Brain Res. 757, 209-217. doi: 10.1016/S0006-8993(97) 00218-7

Bayraktar, T., Welker, E., Freund, T. F., Zilles, K., and Staiger, J. F. (2000). Neurons immunoreactive for vasoactive intestinal polypeptide in the rat primary somatosensory cortex: morphology and spatial relationship to barrelrelated columns. J. Comp. Neurol. 420, 291-304. doi: 10.1002/(SICI)10969861(20000508)420:3<291::AID-CNE2>3.0.CO;2-H

Beierlein, M., Gibson, J. R., and Connors, B. W. (2000). A network of electrically coupled interneurons drives synchronized inhibition in neocortex. Nat. Neurosci. 3, 904-910. doi: 10.1038/78809

Beierlein, M., Gibson, J. R., and Connors, B. W. (2003). Two dynamically distinct inhibitory networks in layer 4 of the neocortex. J. Neurophysiol. 90, 2987-3000. doi: 10.1152/jn.00283.2003

Beinfeld, M. C., Meyer, D. K., Eskay, R. L., Jensen, R. T., and Brownstein, M. J. (1981). The distribution of cholecystokinin immunoreactivity in the central nervous system of the rat as determined by radioimmunoassay. Brain Res. 212, 51-57. doi: 10.1016/0006-8993(81)90031-7
Bergles, D. E., Doze, V. A., Madison, D. V., and Smith, S. J. (1996). Excitatory actions of norepinephrine on multiple classes of hippocampal CA1 interneurons. J. Neurosci. 16, 572-585.

Bhagwandin, A., Fuxe, K., and Manger, P. R. (2006). Choline acetyltransferase immunoreactive cortical interneurons do not occur in all rodents: A study of the phylogenetic occurrence of this neural characteristic. J. Chem. Neuroanat. 32, 208-216. doi: 10.1016/j.jchemneu.2006.09.004

Bodor, A. L., Katona, I., Nyiri, G., Mackie, K., Ledent, C., Hajos, N., et al. (2005). Endocannabinoid signaling in rat somatosensory cortex: laminar differences and involvement of specific interneuron types. J. Neurosci. 25, 6845-6856. doi: 10.1523/JNEUROSCI.0442-05.2005

Bouzier-Sore, A. K., Voisin, P., Canioni, P., Magistretti, P. J., and Pellerin, L. (2003). Lactate is a preferential oxidative energy substrate over glucose for neurons in culture. J. Cereb. Blood Flow Metab. 23, 1298-1306. doi: 10.1097/01.WCB.0000091761.61714.25

Butt, S. J., Fuccillo, M., Nery, S., Noctor, S., Kriegstein, A., Corbin, J. G., et al. (2005). The temporal and spatial origins of cortical interneurons predict their physiological subtype. Neuron 48, 591-604. doi: 10.1016/j.neuron.2005. 09.034

Butt, S. J., Sousa, V. H., Fuccillo, M. V., Hjerling-Leffler, J., Miyoshi, G., Kimura, S., et al. (2008). The requirement of $\mathrm{Nkx2-1}$ in the temporal specification of cortical interneuron subtypes. Neuron 59, 722-732. doi: 10.1016/j.neuron.2008.07.031

Buzsaki, G., Kaila, K., and Raichle, M. (2007). Inhibition and brain work. Neuron 56, 771-783. doi: 10.1016/j.neuron.2007.11.008

Caputi, A., Rozov, A., Blatow, M., and Monyer, H. (2009). Two calretinin-positive GABAergic cell types in layer $2 / 3$ of the mouse neocortex provide different forms of inhibition. Cereb. Cortex 19, 1345-1359. doi: 10.1093/cercor/bhn175

Cataldo, A. M., and Broadwell, R. D. (1986). Cytochemical identification of cerebral glycogen and glucose-6-phosphatase activity under normal and experimental conditions.1. Neurons and Glia. J. Electron Microsc. Tech. 3, 413-437. doi: $10.1002 /$ jemt. 1060030406

Cauli, B., Audinat, E., Lambolez, B., Angulo, M. C., Ropert, N., Tsuzuki, K., et al. (1997). Molecular and physiological diversity of cortical nonpyramidal cells. J. Neurosci. 17, 3894-3906.

Cauli, B., and Hamel, E. (2010). Revisiting the role of neurons in neurovascular coupling. Front. Neuroenergetics 2:9. doi: 10.3389/fnene.2010.00009

Cauli, B., Porter, J. T., Tsuzuki, K., Lambolez, B., Rossier, J., Quenet, B., et al. (2000). Classification of fusiform neocortical interneurons based on unsupervised clustering. Proc. Natl. Acad. Sci. U.S.A. 97, 6144-6149. doi: 10.1073/pnas.97.11.6144

Cauli, B., Tong, X. K., Rancillac, A., Serluca, N., Lambolez, B., Rossier, J., et al. (2004). Cortical GABA interneurons in neurovascular coupling: relays for subcortical vasoactive pathways. J. Neurosci. 24, 8940-8949. doi: 10.1523/JNEUROSCI.3065-04.2004

Chalmers, D. T., Lovenberg, T. W., and De Souza, E. B. (1995). Localization of novel corticotropin-releasing factor receptor (CRF2) mRNA expression to specific subcortical nuclei in rat brain: comparison with CRF1 receptor mRNA expression. J. Neurosci. 15, 6340-6350.

Chaudhuri, J. D., Hiltunen, M., Nykanen, M., Yla-Herttuala, S., Soininen, H., and Miettinen, R. (2005). Localization of M2 muscarinic receptor protein in parvalbumin and calretinin containing cells of the adult rat entorhinal cortex using two complementary methods. Neuroscience 131, 557-566. doi: 10.1016/j.neuroscience.2004.11.032

Chédotal, A., Cozzari, C., Faure, M. P., Hartman, B. K., and Hamel, E. (1994a). Distinct choline acetyltransferase (ChAT) and vasoactive intestinal polypeptide (VIP) bipolar neurons project to local blood vessels in the rat cerebral cortex. Brain Res. 646, 181-193. doi: 10.1016/0006-8993(94)90076-0

Chedotal, A., and Rijli, F. M. (2009). Transcriptional regulation of tangential neuronal migration in the developing forebrain. Curr. Opin. Neurobiol. 19, 139-145. doi: 10.1016/j.conb.2009.04.005

Chédotal, A., Umbriaco, D., Descarries, L., Hartman, B. K., and Hamel, E. (1994b). Light and electron microscopic immunocytochemical analysis of the neurovascular relationships of choline acetyltransferase and vasoactive intestinal polypeptide nerve terminals in the rat cerebral cortex. J. Comp. Neurol. 343, 57-71. doi: 10.1002/cne.903430105

Chittajallu, R., Craig, M. T., McFarland, A., Yuan, X., Gerfen, S., Tricoire, L., et al. (2013). Dual origins of functionally distinct O-LM interneurons revealed by differential 5-HT(3A)R expression. Nat. Neurosci. 16, 1598-1607. doi: 10.1038/nn.3538 
Cho, K. H., Jang, J. H., Jang, H. J., Kim, M. J., Yoon, S. H., Fukuda, T., et al. (2010). Subtype-specific dendritic $\mathrm{Ca}(2+)$ dynamics of inhibitory interneurons in the rat visual cortex. J. Neurophysiol. 104, 840-853. doi: 10.1152/jn.00146.2010

Choi, H. B., Gordon, G. R., Zhou, N., Tai, C., Rungta, R. L., Martinez, J., et al. (2012). Metabolic communication between astrocytes and neurons via bicarbonate-responsive soluble adenylyl cyclase. Neuron 75, 1094-1104. doi: 10.1016/j.neuron.2012.08.032

Choi, J., and Callaway, E. M. (2011). Monosynaptic inputs to ErbB4-expressing inhibitory neurons in mouse primary somatosensory cortex. J. Comp. Neurol. 519, 3402-3414. doi: 10.1002/cne.22680

Choi, J., Young, J. A., and Callaway, E. M. (2010). Selective viral vector transduction of ErbB4 expressing cortical interneurons in vivo with a viral receptorligand bridge protein. Proc. Natl. Acad. Sci. U.S.A. 107, 16703-16708. doi: 10.1073/pnas.1006233107

Ciliax, B. J., Nash, N., Heilman, C., Sunahara, R., Hartney, A., Tiberi, M., et al. (2000). Dopamine $\mathrm{D}(5)$ receptor immunolocalization in rat and monkey brain. Synapse 37, 125-145. doi: 10.1002/1098-2396(200008)37:2<125::AIDSYN7>3.0.CO;2-7

Cobos, I., Calcagnotto, M. E., Vilaythong, A. J., Thwin, M. T., Noebels, J. L., Baraban, S. C., et al. (2005). Mice lacking Dlxl show subtype-specific loss of interneurons, reduced inhibition and epilepsy. Nat. Neurosci. 8, 1059-1068. doi: $10.1038 / \mathrm{nn} 1499$

Consonni, S., Leone, S., Becchetti, A., and Amadeo, A. (2009). Developmental and neurochemical features of cholinergic neurons in the murine cerebral cortex. BMC Neurosci. 10:18. doi: 10.1186/1471-2202-10-18

Dalezios, Y., Lujan, R., Shigemoto, R., Roberts, J. D., and Somogyi, P. (2002). Enrichment of mGluR7a in the presynaptic active zones of GABAergic and nonGABAergic terminals on interneurons in the rat somatosensory cortex. Cereb. Cortex 12, 961-974. doi: 10.1093/cercor/12.9.961

Dávid, C., Schleicher, A., Zuschratter, W., and Staiger, J. F. (2007). The innervation of parvalbumin-containing interneurons by VIP-immunopositive interneurons in the primary somatosensory cortex of the adult rat. Eur. J. Neurosci. 25, 2329-2340. doi: 10.1111/j.1460-9568.2007.05496.x

DeFelipe, J., Lopez-Cruz, P. L., Benavides-Piccione, R., Bielza, C., Larranaga, P., Anderson, S., et al. (2013). New insights into the classification and nomenclature of cortical GABAergic interneurons. Nat. Rev. Neurosci. doi: $10.1038 / \mathrm{nrn} 3444$

De Marco Garcia, N. V., Karayannis, T., and Fishell, G. (2011). Neuronal activity is required for the development of specific cortical interneuron subtypes. Nature 472, 351-355. doi: 10.1038/nature09865

De Michele, M., Touzani, O., Foster, A. C., Fieschi, C., Sette, G., and McCulloch, J. (2005). Corticotropin-releasing factor: effect on cerebral blood flow in physiologic and ischaemic conditions. Exp. Brain Res. 165, 375-382. doi: 10.1007/s00221-005-2303-0

Ding, Y. Q., Shigemoto, R., Takada, M., Ohishi, H., Nakanishi, S., and Mizuno, N. (1996). Localization of the neuromedin K receptor (NK3) in the central nervous system of the rat. J. Comp. Neurol. 364, 290-310.

Donato, F., Rompani, S. B., and Caroni, P. (2013). Parvalbumin-expressing basketcell network plasticity induced by experience regulates adult learning. Nature 504, 272-276. doi: 10.1038/nature 12866

Eckenstein, F., and Baughman, R. W. (1984). Two types of cholinergic innervation in cortex, one co-localized with vasoactive intestinal polypeptide. Nature 309, 153-155. doi: 10.1038/309153a0

Ehmsen, J. T., Ma, T. M., Sason, H., Rosenberg, D., Ogo, T., Furuya, S., et al. (2013). $\mathrm{D}$-serine in glia and neurons derives from 3-phosphoglycerate dehydrogenase. J. Neurosci. 33, 12464-12469. doi: 10.1523/JNEUROSCI.4914-12.2013

Elhusseiny, A., and Hamel, E. (2000). Muscarinic-but not nicotinic-acetylcholine receptors mediate a nitric oxide-dependent dilation in brain cortical arterioles: a possible role for the M5 receptor subtype. J. Cereb. Blood Flow Metab. 20, 298-305. doi: 10.1097/00004647-200002000-00011

Fahrenkrug, J., Hannibal, J., Tams, J., and Georg, B. (2000). Immunohistochemical localization of the VIP1 receptor (VPAC1R) in rat cerebral blood vessels: relation to PACAP and VIP containing nerves. J. Cereb. Blood Flow Metab. 20, 1205-1214. doi: 10.1097/00004647-200008000-00006

Fairen, A., DeFelipe, J., and Regidor, J. (1984). "Nonpyramidal neurons: general account," in Cerebral Cortex, eds A. Peters and E. G. Jones (New York, NY: Plenum Press), 201-253.

Fanselow, E. E., Richardson, K. A., and Connors, B. W. (2008). Selective, state-dependent activation of somatostatin-expressing inhibitory interneurons in mouse neocortex. J. Neurophysiol. 100, 2640-2652. doi: 10.1152/jn.906 91.2008

Férézou, I., Cauli, B., Hill, E. L., Rossier, J., Hamel, E., and Lambolez, B. (2002). 5-HT3 receptors mediate serotonergic fast synaptic excitation of neocortical vasoactive intestinal peptide/cholecystokinin interneurons. J. Neurosci. 22, 7389-7397.

Férézou, I., Hill, E. L., Cauli, B., Gibelin, N., Kaneko, T., Rossier, J., et al. (2007). Extensive overlap of mu-opioid and nicotinic sensitivity in cortical interneurons. Cereb. Cortex 17, 1948-1957. doi: 10.1093/cercor/bhl104

Fergus, A., and Lee, K. S. (1997). GABAergic regulation of cerebral microvascular tone in the rat. J. Cereb. Blood Flow Metab. 17, 992-1003. doi: 10.1097/00004647-199709000-00009

Ferraguti, F., Cobden, P., Pollard, M., Cope, D., Shigemoto, R., Watanabe, M. et al. (2004). Immunolocalization of metabotropic glutamate receptor lalpha (mGluRlalpha) in distinct classes of interneuron in the CA1 region of the rat hippocampus. Hippocampus 14, 193-215. doi: 10.1002/hipo.10163

Flint, A. C., Maisch, U. S., Weishaupt, J. H., Kriegstein, A. R., and Monyer, H. (1997). NR2A subunit expression shortens NMDA receptor synaptic currents in developing neocortex. J. Neurosci. 17, 2469-2476.

Fogarty, M., Grist, M., Gelman, D., Marin, O., Pachnis, V., and Kessaris, N. (2007). Spatial genetic patterning of the embryonic neuroepithelium generates GABAergic interneuron diversity in the adult cortex. J. Neurosci. 27, 10935-10946. doi: 10.1523/JNEUROSCI.1629-07.2007

Fu, Y., Tucciarone, J. M., Espinosa, J. S., Sheng, N., Darcy, D. P., Nicoll, R. A., et al. (2014). A cortical circuit for gain control by behavioral state. Cell 156, 1139-1152. doi: 10.1016/j.cell.2014.01.050

Gabbott, P. L., Dickie, B. G., Vaid, R. R., Headlam, A. J., and Bacon, S. J. (1997). Local-circuit neurones in the medial prefrontal cortex (areas 25, 32 and 24b) in the rat: morphology and quantitative distribution. J. Comp. Neurol. 377, 465-499.

Galea, E., Fernandez-Shaw, C., Triguero, D., and Estrada, C. (1991). Choline acetyltransferase activity associated with cerebral cortical microvessels does not originate in basal forebrain neurons. J. Cereb. Blood Flow Metab. 11, 875-878. doi: 10.1038/jcbfm.1991.148

Gallopin, T., Geoffroy, H., Rossier, J., and Lambolez, B. (2006). Cortical sources of $\mathrm{CRF}, \mathrm{NKB}$, and CCK and their effects on pyramidal cells in the neocortex. Cereb. Cortex 16, 1440-1452. doi: 10.1093/cercor/bhj081

Gelman, D. M., Martini, F. J., Nobrega-Pereira, S., Pierani, A., Kessaris, N., and Marin, O. (2009). The embryonic preoptic area is a novel source of cortical GABAergic interneurons. J. Neurosci. 29, 9380-9389. doi: 10.1523/JNEUROSCI. 0604-09.2009

Gentet, L. J., Kremer, Y., Taniguchi, H., Huang, Z. J., Staiger, J. F., and Petersen, C. C. (2012). Unique functional properties of somatostatin-expressing GABAergic neurons in mouse barrel cortex. Nat. Neurosci. 15, 607-612. doi: 10.1038/ nn.3051

Gilmor, M. L., Nash, N. R., Roghani, A., Edwards, R. H., Yi, H., Hersch, S. M., et al. (1996). Expression of the putative vesicular acetylcholine transporter in rat brain and localization in cholinergic synaptic vesicles. J. Neurosci. 16, 2179-2190.

Glausier, J. R., Khan, Z. U., and Muly, E. C. (2009). Dopamine D1 and D5 receptors are localized to discrete populations of interneurons in primate prefrontal cortex. Cereb. Cortex 19, 1820-1834. doi: 10.1093/cercor/bhn212

Goldberg, J. H., Tamas, G., and Yuste, R. (2003). Ca2+ imaging of mouse neocortical interneurone dendrites: Ia-type $\mathrm{K}+$ channels control action potential backpropagation. J. Physiol. 551, 49-65. doi: 10.1113/jphysiol.2003. 042580

Gonchar, Y., and Burkhalter, A. (1997). Three distinct families of GABAergic neurons in rat visual cortex. Cereb. Cortex 7, 347-358. doi: 10.1093/cercor/7.4.347

Gonchar, Y., and Burkhalter, A. (1999). Connectivity of GABAergic calretininimmunoreactive neurons in rat primary visual cortex. Cereb. Cortex 9, 683-696. doi: 10.1093/cercor/9.7.683

Gonchar, Y., and Burkhalter, A. (2003). Distinct GABAergic targets of feedforward and feedback connections between lower and higher areas of rat visual cortex. J. Neurosci. 23, 10904-10912.

Gonchar, Y., Wang, Q., and Burkhalter, A. (2008). Multiple distinct subtypes of GABAergic neurons in mouse visual cortex identified by triple immunostaining. Front. Neuroanat. 1:3. doi: 10.3389/neuro.05.003.2007

Gonzalez-Albo, M. C., Elston, G. N., and DeFelipe, J. (2001). The human temporal cortex: characterization of neurons expressing nitric oxide synthase, 
neuropeptides and calcium-binding proteins, and their glutamate receptor subunit profiles. Cereb. Cortex 11, 1170-1181. doi: 10.1093/cercor/11.12.1170

Gulledge, A. T., Park, S. B., Kawaguchi, Y., and Stuart, G. (2006). Heterogeneity of phasic cholinergic signalling in neocortical neurons. J. Neurophysiol. 97, 2215-2229. doi: 10.1152/jn.00493.2006

Gulyas, A. I., Hajos, N., and Freund, T. F. (1996). Interneurons containing calretinin are specialized to control other interneurons in the rat hippocampus. J. Neurosci. 16, 3397-3411.

Hajos, F., Staiger, J. F., Halasy, K., Freund, T. F., and Zilles, K. (1997). Geniculocortical afferents form synaptic contacts with vasoactive intestinal polypeptide (VIP) immunoreactive neurons of the rat visual cortex. Neurosci. Lett. 228, 179-182. doi: 10.1016/S0304-3940(97)00399-6

Halabisky, B. E., Shen, F., Huguenard, J. R., and Prince, D. A. (2006). Electrophysiological classification of somatostatin-positive interneurons in mouse sensorimotor cortex. J Neurophysiol. 96, 834-845. doi: 10.1152/jn.01079.2005

Hangya, B., Pi, H. J., Kvitsiani, D., Ranade, S. P., and Kepecs, A. (2014). From circuit motifs to computations: mapping the behavioral repertoire of cortical interneurons. Curr. Opin. Neurobiol. 26C, 117-124. doi: 10.1016/j.conb.2014.01.007

Haug, T., and Storm, J. F. (2000). Protein kinase A mediates the modulation of the slow $\mathrm{Ca}(2+)$-dependent $\mathrm{K}(+)$ current, I(sAHP), by the neuropeptides CRF, VIP, and CGRP in hippocampal pyramidal neurons. J. Neurophysiol. 83, 2071-2079.

Hauger, R. L., Smith, R. D., Braun, S., Dautzenberg, F. M., and Catt, K. J. (2000). Rapid agonist-induced phosphorylation of the human CRF receptor, type 1: a potential mechanism for homologous desensitization. Biochem. Biophys. Res. Commun. 268, 572-576. doi: 10.1006/bbrc.2000.2183

Herrero-Mendez, A., Almeida, A., Fernandez, E., Maestre, C., Moncada, S., and Bolanos, J. P. (2009). The bioenergetic and antioxidant status of neurons is controlled by continuous degradation of a key glycolytic enzyme by APC/C-Cdh1. Nat. Cell Biol. 11, 747-752. doi: 10.1038/ncb1881

Hill, E. L., Gallopin, T., Férézou, I., Cauli, B., Rossier, J., Schweitzer, P., et al. (2007). Functional CB1 receptors are broadly expressed in neocortical GABAergic and glutamatergic neurons. J. Neurophysiol. 97, 2580-2589. doi: 10.1152/jn.00603.2006

Hioki, H., Okamoto, S., Konno, M., Kameda, H., Sohn, J., Kuramoto, E., et al. (2013). Cell type-specific inhibitory inputs to dendritic and somatic compartments of parvalbumin-expressing neocortical interneuron. J. Neurosci. 33, 544-555. doi: 10.1523/JNEUROSCI.2255-12.2013

Hu, E., Demmou, L., Cauli, B., Gallopin, T., Geoffroy, H., Harris-Warrick, R. M., et al. (2011). VIP, CRF, and PACAP act at distinct receptors to elicit different cAMP/PKA dynamics in the neocortex. Cereb. Cortex 21, 708-718. doi: 10.1093/cercor/bhq143

Isaacson, J. S., and Scanziani, M. (2011). How inhibition shapes cortical activity. Neuron 72, 231-243. doi: 10.1016/j.neuron.2011.09.027

Itakura, T., Yokote, H., Okuno, T., Naka, Y., Nakakita, K., Kamei, I., et al. (1987). Regulation of rCBF by intracortical vasoactive intestinal polypeptide- containing neurons. Immunohistochemical and hydrogen clearance study in rats. J. Neurosurg. 67, 93-96. doi: 10.3171/jns.1987.67.1.0093

Jacobowitz, D. M., and Winsky, L. (1991). Immunocytochemical localization of calretinin in the forebrain of the rat. J. Comp. Neurol. 304, 198-218. doi: $10.1002 /$ cne. 903040205

Jakab, R. L., and Goldman-Rakic, P. S. (2000). Segregation of serotonin 5HT2A and 5-HT3 receptors in inhibitory circuits of the primate cerebral cortex. J. Comp. Neurol. 417, 337-348. doi: 10.1002/(SICI)10969861(20000214)417:3<337::AID-CNE7>3.0.CO;2-O

Jonas, P., Racca, C., Sakmann, B., Seeburg, P. H., and Monyer, H. (1994). Differences in Ca2 + permeability of AMPA-type glutamate receptor channels in neocortical neurons caused by differential GluR-B subunit expression. Neuron 12, 1281-1289. doi: 10.1016/0896-6273(94)90444-8

Jones, E. G. (1975). Varieties and distribution of non-pyramidal cells in the somatic sensory cortex of the squirrel monkey. J. Comp. Neurol. 160, 205-267. doi: $10.1002 / \mathrm{cne} .901600204$

Kaiser, K. M., Zilberter, Y., and Sakmann, B. (2001). Back-propagating action potentials mediate calcium signalling in dendrites of bitufted interneurons in layer $2 / 3$ of rat somatosensory cortex. J. Physiol. 535, 17-31. doi: 10.1111/j.14697793.2001.t01-1-00017.x

Kanatani, S., Yozu, M., Tabata, H., and Nakajima, K. (2008). COUP-TFII is preferentially expressed in the caudal ganglionic eminence and is involved in the caudal migratory stream. J. Neurosci. 28, 13582-13591. doi: 10.1523/JNEUROSCI.2132-08.2008

Kaneko, T., Murashima, M., Lee, T., and Mizuno, N. (1998). Characterization of neocortical non-pyramidal neurons expressing preprotachykinins A and B: a double immunofluorescence study in the rat. Neuroscience 86, 765-781. doi: 10.1016/S0306-4522(98)00036-0

Karagiannis, A., Gallopin, T., David, C., Battaglia, D., Geoffroy, H., Rossier, J., et al. (2009). Classification of NPY-expressing neocortical interneurons. J. Neurosci. 29, 3642-3659. doi: 10.1523/JNEUROSCI.0058-09.2009

Karnani, M. M., Agetsuma, M., and Yuste, R. (2014). A blanket of inhibition: functional inferences from dense inhibitory connectivity. Curr. Opin. Neurobiol. 26C, 96-102. doi: 10.1016/j.conb.2013.12.015

Kawaguchi, Y. (1997). Selective cholinergic modulation of cortical GABAergic cell subtypes. J. Neurophysiol. 78, 1743-1747.

Kawaguchi, Y., and Kubota, Y. (1993). Correlation of physiological subgroupings of nonpyramidal cells with parvalbumin- and calbindinD28k-immunoreactive neurons in layer V of rat frontal cortex. J. Neurophysiol. 70, 387-396.

Kawaguchi, Y., and Kubota, Y. (1996). Physiological and morphological identification of somatostatin- or vasoactive intestinal polypeptide-containing cells among GABAergic cell subtypes in rat frontal cortex. J. Neurosci. 16, 2701-2715.

Kawaguchi, Y., and Shindou, T. (1998). Noradrenergic excitation and inhibition of GABAergic cell types in rat frontal cortex. J. Neurosci. 18, 6963-6976.

Kerner, J. A., Standaert, D. G., Penney, J. B. Jr., Young, A. B., and Landwehrmeyer, G. B. (1997). Expression of group one metabotropic glutamate receptor subunit mRNAs in neurochemically identified neurons in the rat neostriatum, neocortex, and hippocampus. Brain Res. Mol. Brain Res. 48, 259-269. doi: 10.1016/S0169-328X(97)00102-2

Kessaris, N., Magno, L., Rubin, A. N., and Oliveira, M. G. (2014). Genetic programs controlling cortical interneuron fate. Curr. Opin. Neurobiol. 26C, 79-87. doi: 10.1016/j.conb.2013.12.012

Khan, Z. U., Gutierrez, A., Martin, R., Penafiel, A., Rivera, A., and de la Calle, A. (1998). Differential regional and cellular distribution of dopamine D2-like receptors: an immunocytochemical study of subtype-specific antibodies in rat and human brain. J. Comp. Neurol. 402, 353-371.

Khan, Z. U., Gutierrez, A., Martin, R., Penafiel, A., Rivera, A., and de la Calle, A. (2000). Dopamine D5 receptors of rat and human brain. Neuroscience 100, 689-699. doi: 10.1016/S0306-4522(00)00274-8

Klausberger, T., and Somogyi, P. (2008). Neuronal diversity and temporal dynamics: the unity of hippocampal circuit operations. Science 321, 53-57. doi: 10.1126/science. 1149381

Kleinfeld, D., Blinder, P., Drew, P. J., Driscoll, J. D., Muller, A., Tsai, P. S., et al. (2011). A guide to delineate the logic of neurovascular signaling in the brain. Front. Neuroenergetics 3:1. doi: 10.3389/fnene.2011.00001

Kocharyan, A., Fernandes, P., Tong, X. K., Vaucher, E., and Hamel, E. (2008). Specific subtypes of cortical GABA interneurons contribute to the neurovascular coupling response to basal forebrain stimulation. J. Cereb. Blood Flow Metab. 28, 221-231. doi: 10.1038/sj.jcbfm.9600558

Kosaka, T., Tauchi, M., and Dahl, J. L. (1988). Cholinergic neurons containing GABA-like and/or glutamic acid decarboxylase-like immunoreactivities in various brain regions of the rat. Exp. Brain Res. 70, 605-617. doi: 10.1007/BF00247609

Kubota, Y., Hattori, R., and Yui, Y. (1994). Three distinct subpopulations of GABAergic neurons in rat frontal agranular cortex. Brain Res. 649, 159-173. doi: 10.1016/0006-8993(94)91060-X

Kubota, Y., and Kawaguchi, Y. (1997). Two distinct subgroups of cholecystokininimmunoreactive cortical interneurons. Brain Res. 752, 175-183. doi: 10.1016/S0006-8993(96)01446-1

Kubota, Y., Shigematsu, N., Karube, F., Sekigawa, A., Kato, S., Yamaguchi, N., et al. (2011). Selective coexpression of multiple chemical markers defines discrete populations of neocortical GABAergic neurons. Cereb. Cortex 21, 1803-1817. doi: 10.1093/cercor/bhq252

Kwan, K. Y., Lam, M. M., Johnson, M. B., Dube, U., Shim, S., Rasin, M. R., et al. (2012). Species-dependent posttranscriptional regulation of NOS1 by FMRP in the developing cerebral cortex. Cell 149, 899-911. doi: 10.1016/j.cell.2012.02.060

Lambolez, B., Ropert, N., Perrais, D., Rossier, J., and Hestrin, S. (1996). Correlation between kinetics and RNA splicing of alpha-amino-3-hydroxy-5methylisoxazole-4-propionic acid receptors in neocortical neurons. Proc. Natl. Acad. Sci. U.S.A. 93, 1797-1802. doi: 10.1073/pnas.93.5.1797 
Laurie, D. J., Wisden, W., and Seeburg, P. H. (1992). The distribution of thirteen GABAA receptor subunit mRNAs in the rat brain. III. Embryonic and postnatal development. J. Neurosci. 12, 4151-4172.

Lecrux, C., Toussay, X., Kocharyan, A., Fernandes, P., Neupane, S., Levesque, M., et al. (2011). Pyramidal neurons are "neurogenic hubs" in the neurovascular coupling response to whisker stimulation. J. Neurosci. 31, 9836-9847. doi: 10.1523/JNEUROSCI.4943-10.2011

Lee, J. E., and Jeon, C. J. (2005). Immunocytochemical localization of nitric oxide synthase-containing neurons in mouse and rabbit visual cortex and co-localization with calcium-binding proteins. Mol. Cells 19, 408-417.

Lee, M. G., Hassani, O. K., Alonso, A., and Jones, B. E. (2005). Cholinergic basal forebrain neurons burst with theta during waking and paradoxical sleep. J. Neurosci. 25, 4365-4369. doi: 10.1523/JNEUROSCI.0178-05.2005

Lee, S., Hjerling-Leffler, J., Zagha, E., Fishell, G., and Rudy, B. (2010). The largest group of superficial neocortical GABAergic interneurons expresses ionotropic serotonin receptors. J. Neurosci. 30, 16796-16808. doi: 10.1523/JNEUROSCI.1869-10.2010

Lee, S., Kruglikov, I., Huang, Z. J., Fishell, G., and Rudy, B. (2013). A disinhibitory circuit mediates motor integration in the somatosensory cortex. Nat. Neurosci. 16, 1662-1670. doi: 10.1038/nn.3544

Lee, T. J., Saito, A., and Berezin, I. (1984). Vasoactive intestinal polypeptidelike substance: the potential transmitter for cerebral vasodilation. Science 224, 898-901. doi: 10.1126/science.6719122

Leithner, C., Royl, G., Offenhauser, N., Fuchtemeier, M., Kohl-Bareis, M., Villringer, A., et al. (2010). Pharmacological uncoupling of activation induced increases in CBF and CMRO(2). J. Cereb. Blood Flow Metab. 30, 311-322. doi: 10.1038/jcbfm.2009.211

Liu, S., Bubar, M. J., Lanfranco, M. F., Hillman, G. R., and Cunningham, K. A. (2007). Serotonin2C receptor localization in GABA neurons of the rat medial prefrontal cortex: implications for understanding the neurobiology of addiction. Neuroscience 146, 1677-1688. doi: 10.1016/j.neuroscience.2007. 02.064

Liu, X., Li, C., Falck, J. R., Harder, D. R., and Koehler, R. C. (2012). Relative contribution of cyclooxygenases, epoxyeicosatrienoic acids, and $\mathrm{pH}$ to the cerebral blood flow response to vibrissal stimulation. Am. J. Physiol. Heart Circ. Physiol. 302, H1075-H1085. doi: 10.1152/ajpheart.00794.2011

Liu, Y., Liang, X., Ren, W. W., and Li, B. M. (2014). Expression of beta1- and beta2-adrenoceptors in different subtypes of interneurons in the medial prefrontal cortex of mice. Neuroscience 257, 149-157. doi: 10.1016/j.neuroscience.2013.10.078

Lodato, S., Tomassy, G. S., De, L. E., Uzcategui, Y. G., Andolfi, G., Armentano, M., et al. (2011). Loss of COUP-TFI alters the balance between caudal ganglionic eminence- and medial ganglionic eminence-derived cortical interneurons and results in resistance to epilepsy. J. Neurosci. 31, 4650-4662. doi: 10.1523/JNEUROSCI.6580-10.2011

Long, J. B., Rigamonti, D. D., Dosaka, K., Kraimer, J. M., and Martinez-Arizala, A. (1992). Somatostatin causes vasoconstriction, reduces blood flow and increases vascular permeability in the rat central nervous system. J. Pharmacol. Exp. Ther. 260, 1425-1432.

Ma, Y., Hu, H., Berrebi, A. S., Mathers, P. H., and Agmon, A. (2006). Distinct subtypes of somatostatin-containing neocortical interneurons revealed in transgenic mice. J. Neurosci. 26, 5069-5082. doi: 10.1523/JNEUROSCI.0661-06.2006

Magistretti, P. J. (1990). VIP neurons in the cerebral cortex. TIPS 11, 250-254. doi: 10.1016/0165-6147(90)90253-5

Magistretti, P. J., Morrison, J. H., Shoemaker, W. J., and Bloom, F. E. (1984). Morphological and functional correlates of VIP neurons in cerebral cortex. Peptides 5, 213-218. doi: 10.1016/0196-9781(84)90209-2

Magistretti, P. J., Morrison, J. H., Shoemaker, W. J., Sapin, V., and Bloom, F. E. (1981). Vasoactive intestinal polypeptide induces glycogenolysis in mouse cortical slices: a possible regulatory mechanism for the local control of energy metabolism. Proc. Natl. Acad. Sci. U.S.A. 78, 6535-6539. doi: 10.1073/pnas.78.10.6535

Magistretti, P. J., and Schorderet, M. (1984). VIP and noradrenaline act synergistically to increase cyclic AMP in cerebral cortex. Nature 308, 280-282. doi: 10.1038/308280a0

Magno, L., Oliveira, M. G., Mucha, M., Rubin, A. N., and Kessaris, N. (2012). Multiple embryonic origins of nitric oxide synthase-expressing GABAergic neurons of the neocortex. Front. Neural Circuits 6:65. doi: 10.3389/fncir.2012. 00065
Marek, G. J., and Aghajanian, G. K. (1996). Alpha 1B-adrenoceptor-mediated excitation of piriform cortical interneurons. Eur. J. Pharmacol. 305, 95-100. doi: 10.1016/0014-2999(96)00158-6

Marin, O. (2013). Cellular and molecular mechanisms controlling the migration of neocortical interneurons. Eur. J. Neurosci. 38, 2019-2029. doi: 10.1111/ejn.12225

Martin, J. L., Feinstein, D. L., Yu, N., Sorg, O., Rossier, C., and Magistretti, P. J. (1992). VIP receptor subtypes in mouse cerebral cortex: evidence for a differential localization in astrocytes, microvessels and synaptosomal membranes. Brain Res. 587, 1-12. doi: 10.1016/0006-8993(92)91423-C

Melvin, N. R., and Dyck, R. H. (2003). Developmental distribution of calretinin in mouse barrel cortex. Brain Res. Dev. Brain Res. 143, 111-114. doi: 10.1016/S0165-3806(03)00102-0

Meskenaite, V. (1997). Calretinin-immunoreactive local circuit neurons in area 17 of the cynomolgus monkey, Macaca fascicularis. J. Comp. Neurol. 379, 113-132.

Miyoshi, G., Butt, S. J., Takebayashi, H., and Fishell, G. (2007). Physiologically distinct temporal cohorts of cortical interneurons arise from telencephalic Olig2-expressing precursors. J. Neurosci. 27, 7786-7798. doi: 10.1523/JNEUROSCI.1807-07.2007

Miyoshi, G., Hjerling-Leffler, J., Karayannis, T., Sousa, V. H., Butt, S. J., Battiste, J., et al. (2010). Genetic fate mapping reveals that the caudal ganglionic eminence produces a large and diverse population of superficial cortical interneurons. J. Neurosci. 30, 1582-1594. doi: 10.1523/JNEUROSCI.4515-09.2010

Molyneaux, B. J., Arlotta, P., Menezes, J. R., and Macklis, J. D. (2007). Neuronal subtype specification in the cerebral cortex. Nat. Rev. Neurosci. 8, 427-437. doi: $10.1038 / \mathrm{nrn} 2151$

Morales, M., and Bloom, F. E. (1997). The 5-HT3 receptor is present in different subpopulations of GABAergic neurons in the rat telencephalon. J. Neurosci. 17, 3157-3167.

Morrison, J. H., Magistretti, P. J., Benoit, R., and Bloom, F. E. (1984). The distribution and morphological characteristics of the intracortical VIP-positive cell: an immunohistochemical analysis. Brain Res. 292, 269-282. doi: 10.1016/00068993(84)90763-7

Munoz, W., and Rudy, B. (2014). Spatiotemporal specificity in cholinergic control of neocortical function. Curr. Opin. Neurobiol. 26C, 149-160. doi: 10.1016/j.conb.2014.02.015

Murphy, P. C., Grieve, K. L., and Sillito, A. M. (1993). Effects of vasoactive intestinal polypeptide on the response properties of cells in area 17 of the cat visual cortex. J. Neurophysiol. 69, 1465-1474.

Nicholas, A. P., Pieribone, V., and Hokfelt, T. (1993a). Distributions of mRNAs for alpha-2 adrenergic receptor subtypes in rat brain: an in situ hybridization study. J. Comp. Neurol. 328, 575-594. doi: 10.1002/cne.903280409

Nicholas, A. P., Pieribone, V. A., and Hokfelt, T. (1993b). Cellular localization of messenger RNA for beta- 1 and beta- 2 adrenergic receptors in rat brain: an in situ hybridization study. Neuroscience 56, 1023-1039. doi: 10.1016/03064522(93)90148-9

Oda, S., Funato, H., chi-Akahane, S., Ito, M., Okada, A., Igarashi, H., et al. (2010). Dopamine D5 receptor immunoreactivity is differentially distributed in GABAergic interneurons and pyramidal cells in the rat medial prefrontal cortex. Brain Res. 1329, 89-102. doi: 10.1016/j.brainres.2010.03.011

Okaty, B. W., Miller, M. N., Sugino, K., Hempel, C. M., and Nelson, S. B. (2009). Transcriptional and electrophysiological maturation of neocortical fast-spiking GABAergic interneurons. J. Neurosci. 29, 7040-7052. doi: 10.1523/JNEUROSCI.0105-09.2009

Olah, S., Fule, M., Komlosi, G., Varga, C., Baldi, R., Barzo, P., et al. (2009) Regulation of cortical microcircuits by unitary GABA-mediated volume transmission. Nature 461, 1278-1281. doi: 10.1038/nature08503

Panatier, A., Theodosis, D. T., Mothet, J. P., Touquet, B., Pollegioni, L., Poulain, D. A., et al. (2006). Glia-derived D-serine controls NMDA receptor activity and synaptic memory. Cell 125, 775-784. doi: 10.1016/j.cell.2006.02.051

Paspalas, C. D., and Papadopoulos, G. C. (1998). Ultrastructural evidence for combined action of noradrenaline and vasoactive intestinal polypeptide upon neurons, astrocytes, and blood vessels of the rat cerebral cortex. Brain Res. Bull. 45, 247-259. doi: 10.1016/S0361-9230(97)00327-4

Paspalas, C. D., and Papadopoulos, G. C. (1999). Noradrenergic innervation of peptidergic interneurons in the rat visual cortex. Cereb. Cortex 9, 844-853. doi: $10.1093 /$ cercor/9.8.844

Paspalas, C. D., and Papadopoulos, G. C. (2001). Serotoninergic afferents preferentially innervate distinct subclasses of peptidergic interneurons in the 
rat visual cortex. Brain Res. 891, 158-167. doi: 10.1016/S0006-8993(00) 03193-0

Pellerin, L., and Magistretti, P. J. (1994). Glutamate uptake into astrocytes stimulates aerobic glycolysis: a mechanism coupling neuronal activity to glucose utilization. Proc. Natl. Acad. Sci. U.S.A. 91, 10625-10629. doi: 10.1073/pnas.91.22.10625

Perrenoud, Q., Geoffroy, H., Gauthier, B., Rancillac, A., Alfonsi, F., Kessaris, N., et al. (2012a). Characterization of type I and type, I. I. nNOS-expressing interneurons in the barrel cortex of mouse. Front. Neural Circuits 6:36. doi: 10.3389/fncir.2012.00036

Perrenoud, Q., Rossier, J., Ferezou, I., Geoffroy, H., Gallopin, T., Vitalis, T., et al. (2012b). Activation of cortical 5-HT(3) receptor-expressing interneurons induces NO mediated vasodilatations and NPY mediated vasoconstrictions. Front. Neural Circuits 6:50. doi: 10.3389/fncir.2012.00050

Perrenoud, Q., Rossier, J., Geoffroy, H., Vitalis, T., and Gallopin, T. (2013). Diversity of GABAergic interneurons in layer VIa and VIb of mouse barrel cortex. Cereb Cortex 23, 423-441. doi: 10.1093/cercor/bhs032

Peters, A., and Harriman, K. M. (1988). Enigmatic bipolar cell of rat visual cortex. J. Comp. Neurol. 267, 409-432. doi: 10.1002/cne.902670310

Pfeffer, C. K., Xue, M., He, M., Huang, Z. J., and Scanziani, M. (2013). Inhibition of inhibition in visual cortex: the logic of connections between molecularly distinct interneurons. Nat. Neurosci. 16, 1068-1076. doi: 10.1038/nn.3446

Pi, H. J., Hangya, B., Kvitsiani, D., Sanders, J. I., Huang, Z. J., and Kepecs, A. (2013). Cortical interneurons that specialize in disinhibitory control. Nature 503, 521-524. doi: 10.1038/nature12676

Pieribone, V. A., Nicholas, A. P., Dagerlind, A., and Hokfelt, T. (1994). Distribution of alpha 1 adrenoceptors in rat brain revealed by in situ hybridization experiments utilizing subtype-specific probes. J. Neurosci. 14, 4252-4268.

Pirker, S., Schwarzer, C., Wieselthaler, A., Sieghart, W., and Sperk, G. (2000). GABA(A) receptors: immunocytochemical distribution of 13 subunits in the adult rat brain. Neuroscience 101, 815-850. doi: 10.1016/S03064522(00)00442-5

Pohlkamp, T., David, C., Cauli, B., Gallopin, T., Bouche, E., Karagiannis, A., et al. (2013). Characterization and distribution of reelin-positive interneuron subtypes in the rat barrel cortex. Cereb. Cortex. doi: 10.1093/cercor/bht161. [Epub ahead of print].

Porter, J. T., Cauli, B., Staiger, J. F., Lambolez, B., Rossier, J., and Audinat, E. (1998). Properties of bipolar VIPergic interneurons and their excitation by pyramidal neurons in the rat neocortex. Eur. J. Neurosci. 10, 3617-3628. doi: 10.1046/j.1460-9568.1998.00367.x

Porter, J. T., Cauli, B., Tsuzuki, K., Lambolez, B., Rossier, J., and Audinat, E. (1999). Selective excitation of subtypes of neocortical interneurons by nicotinic receptors. J. Neurosci. 19, 5228-5235.

Rakic, P. (2007). The radial edifice of cortical architecture: from neuronal silhouettes to genetic engineering. Brain Res. Rev. 55, 204-219. doi: 10.1016/j.brainresrev.2007.02.010

Ramón y Cajal, S. (1995). "General structure of the cerebral cortex," in Histology of the Nervous System, Transl. eds N. Swanson and R. W. Swanson (New York, NY: Oxford University Press), 429-492.

Rekling, J. C. (2004). NK-3 receptor activation depolarizes and induces an afterdepolarization in pyramidal neurons in gerbil cingulate cortex. Brain Res. Bull. 63, 85-90. doi: 10.1016/j.brainresbull.2004.01.004

Resibois, A., and Rogers, J. H. (1992). Calretinin in rat brain: an immunohistochemical study. Neuroscience 46, 101-134. doi: 10.1016/0306-4522(92)90012-Q

Reyes, A., Lujan, R., Rozov, A., Burnashev, N., Somogyi, P., and Sakmann, B. (1998). Target-cell-specific facilitation and depression in neocortical circuits. Nat. Neurosci. 1, 279-285. doi: 10.1038/1092

Rivera, A., Penafiel, A., Megias, M., Agnati, L. F., Lopez-Tellez, J. F., Gago, B., et al. (2008). Cellular localization and distribution of dopamine $\mathrm{D}(4)$ receptors in the rat cerebral cortex and their relationship with the cortical dopaminergic and noradrenergic nerve terminal networks. Neuroscience 155, 997-1010. doi: 10.1016/j.neuroscience.2008.05.060

Rogers, J. H. (1992). Immunohistochemical markers in rat cortex: co-localization of calretinin and calbindin-D28k with neuropeptides and GABA. Brain Res. 587, 147-157. doi: 10.1016/0006-8993(92)91439-L

Rozov, A., Jerecic, J., Sakmann, B., and Burnashev, N. (2001). AMPA receptor channels with long-lasting desensitization in bipolar interneurons contribute to synaptic depression in a novel feedback circuit in layer $2 / 3$ of rat neocortex. J. Neurosci. 21, 8062-8071.
Ruano, D., Perrais, D., Rossier, J., and Ropert, N. (1997). Expression of GABA(A) receptor subunit mRNAs by layer $\mathrm{V}$ pyramidal cells of the rat primary visual cortex. Eur. J. Neurosci. 9, 857-862. doi: 10.1111/j.1460-9568.1997.tb 01435.x

Rudy, B., Fishell, G., Lee, S., and Hjerling-Leffler, J. (2011). Three groups of interneurons account for nearly $100 \%$ of neocortical GABAergic neurons. Dev. Neurobiol. 71, 45-61. doi: 10.1002/dneu.20853

Ruminot, I., Gutierrez, R., Pena-Munzenmayer, G., Anazco, C., Sotelo-Hitschfeld, T., Lerchundi, R., et al. (2011). NBCel mediates the acute stimulation of astrocytic glycolysis by extracellular K+. J. Neurosci. 31, 14264-14271. doi: 10.1523/JNEUROSCI.2310-11.2011

Santana, N., Bortolozzi, A., Serrats, J., Mengod, G., and Artigas, F. (2004). Expression of serotonin1A and serotonin2A receptors in pyramidal and GABAergic neurons of the rat prefrontal cortex. Cereb. Cortex 14, 1100-1109. doi: 10.1093/cercor/bhh070

Schafer, M. K., Weihe, E., Erickson, J. D., and Eiden, L. E. (1995). Human and monkey cholinergic neurons visualized in paraffin-embedded tissues by immunoreactivity for VAChT, the vesicular acetylcholine transporter. J. Mol. Neurosci. 6, 225-235. doi: 10.1007/BF02736782

Schafer, M. K., Weihe, E., Varoqui, H., Eiden, L. E., and Erickson, J. D. (1994). Distribution of the vesicular acetylcholine transporter (VAChT) in the central and peripheral nervous systems of the rat. J. Mol. Neurosci. 5, 1-26. doi: 10.1007/BF02736691

Scheinin, M., Lomasney, J. W., Hayden-Hixson, D. M., Schambra, U. B., Caron, M. G., Lefkowitz, R. J., et al. (1994). Distribution of alpha 2-adrenergic receptor subtype gene expression in rat brain. Brain Res. Mol. Brain Res. 21, 133-149. doi: 10.1016/0169-328X(94)90386-7

Schwaller, B. (2014). Calretinin: from a "simple" Ca buffer to a multifunctional protein implicated in many biological processes. Front. Neuroanat. 8:3. doi: 10.3389/fnana.2014.00003

Sesack, S. R., Bressler, C. N., and Lewis, D. A. (1995a). Ultrastructural associations between dopamine terminals and local circuit neurons in the monkey prefrontal cortex: a study of calretinin-immunoreactive cells. Neurosci. Lett. 200, 9-12. doi: 10.1016/0304-3940(95)12076-G

Sesack, S. R., Snyder, C. L., and Lewis, D. A. (1995b). Axon terminals immunolabeled for dopamine or tyrosine hydroxylase synapse on GABA-immunoreactive dendrites in rat and monkey cortex. J. Comp. Neurol. 363, 264-280. doi: $10.1002 /$ cne. 903630208

Shigemoto, R., Yokota, Y., Tsuchida, K., and Nakanishi, S. (1990). Cloning and expression of a rat neuromedin K receptor cDNA. J. Biol. Chem. 265, 623-628.

Shughrue, P. J., Lane, M. V., and Merchenthaler, I. (1996). In situ hybridization analysis of the distribution of neurokinin-3 mRNA in the rat central nervous system. J. Comp. Neurol. 372, 395-414.

Sorg, O., and Magistretti, P. J. (1992). Vasoactive intestinal peptide and noradrenaline exert long-term control on glycogen levels in astrocytes: blockade by protein synthesis inhibition. J. Neurosci. 12, 4923-4931.

Stacey, A. E., Woodhall, G. L., and Jones, R. S. (2002). Neurokinin-receptormediated depolarization of cortical neurons elicits an increase in glutamate release at excitatory synapses. Eur. J. Neurosci. 16, 1896-1906. doi: 10.1046/j.1460-9568.2002.02266.x

Staiger, J. F., Masanneck, C., Schleicher, A., and Zuschratter, W. (2004). Calbindincontaining interneurons are a target for VIP-immunoreactive synapses in rat primary somatosensory cortex. J. Comp. Neurol. 468, 179-189. doi: 10.1002/cne.10953

Staiger, J. F., Zilles, K., and Freund, T. F. (1996). Innervation of VIPimmunoreactive neurons by the ventroposteromedial thalamic nucleus in the barrel cortex of the rat. J. Comp. Neurol. 367, 194-204.

Suzuki, A., Stern, S. A., Bozdagi, O., Huntley, G. W., Walker, R. H., Magistretti, P. J., et al. (2011). Astrocyte-neuron lactate transport is required for long-term memory formation. Cell 144, 810-823. doi: 10.1016/j.cell.2011. 02.018

Taki, K., Kaneko, T., and Mizuno, N. (2000). A group of cortical interneurons expressing mu-opioid receptor-like immunoreactivity: a double immunofluorescence study in the rat cerebral cortex. Neuroscience 98, 221-231. doi: 10.1016/S0306-4522(00)00124-X

Tamamaki, N., Yanagawa, Y., Tomioka, R., Miyazaki, J., Obata, K., and Kaneko, T. (2003). Green fluorescent protein expression and colocalization with calretinin, parvalbumin, and somatostatin in the GAD67-GFP knock-in mouse. J. Comp. Neurol. 467, 60-79. doi: 10.1002/cne.10905 
Taniguchi, H., He, M., Wu, P., Kim, S., Paik, R., Sugino, K., et al. (2011). A resource of Cre driver lines for genetic targeting of GABAergic neurons in cerebral cortex. Neuron 71, 995-1013. doi: 10.1016/j.neuron.2011.07.026

Toledo-Rodriguez, M., Goodman, P., Illic, M., Wu, C., and Markram, H. (2005). Neuropeptide and calcium binding protein gene expression profiles predict neuronal anatomical type in the juvenile rat. J. Physiol. 567, 401-413. doi: 10.1113/jphysiol.2005.089250

Toussay, X., Basu, K., Lacoste, B., and Hamel, E. (2013). Locus coeruleus stimulation recruits a broad cortical neuronal network and increases cortical perfusion. J. Neurosci. 33, 3390-3401. doi: 10.1523/JNEUROSCI.3346-12.2013

Tricoire, L., Pelkey, K. A., Daw, M. I., Sousa, V. H., Miyoshi, G., Jeffries, B., et al. (2010). Common origins of hippocampal ivy and nitric oxide synthase expressing neurogliaform cells. J. Neurosci. 30, 2165-2176. doi: 10.1523/JNEUROSCI.5123-09.2010

Tricoire, L., Pelkey, K. A., Erkkila, B. E., Jeffries, B. W., Yuan, X., and McBain, C. J. (2011). A blueprint for the spatiotemporal origins of mouse hippocampal interneuron diversity. J. Neurosci. 31, 10948-10970. doi: 10.1523/JNEUROSCI. 0323-11.2011

Tripodi, M., Filosa, A., Armentano, M., and Studer, M. (2004). The COUP-TF nuclear receptors regulate cell migration in the mammalian basal forebrain. Development 131, 6119-6129. doi: 10.1242/dev.01530

van Hooft, J. A., Giuffrida, R., Blatow, M., and Monyer, H. (2000). Differential expression of group I metabotropic glutamate receptors in functionally distinct hippocampal interneurons. J. Neurosci. 20, 3544-3551.

Venkatesan, C., Song, X. Z., Go, C. G., Kurose, H., and Aoki, C. (1996). Cellular and subcellular distribution of alpha 2A-adrenergic receptors in the visual cortex of neonatal and adult rats. J. Comp. Neurol. 365, 79-95.

Vicini, S., Wang, J. F., Li, J. H., Zhu, W. J., Wang, Y. H., Luo, J. H., et al. (1998). Functional and pharmacological differences between recombinant N-methylD-aspartate receptors. J. Neurophysiol. 79, 555-566.

Vincent, S. L., Khan, Y., and Benes, F. M. (1993). Cellular distribution of dopamine D1 and D2 receptors in rat medial prefrontal cortex. J. Neurosci. 13, 2551-2564.

Von Engelhardt, J., Eliava, M., Meyer, A. H., Rozov, A., and Monyer, H. (2007). Functional characterization of intrinsic cholinergic interneurons in the cortex. J. Neurosci. 27, 5633-5642. doi: 10.1523/JNEUROSCI.4647-06.2007

Vucurovic, K., Gallopin, T., Ferezou, I., Rancillac, A., Chameau, P., van Hooft, J. A., et al. (2010). Serotonin 3A receptor subtype as an early and protracted marker of cortical interneuron subpopulations. Cereb. Cortex 20, 2333-2347. doi: 10.1093/cercor/bhp310

Wang, Y., Gupta, A., Toledo-Rodriguez, M., Wu, C. Z., and Markram, H. (2002). Anatomical, physiological, molecular and circuit properties of nest basket cells in the developing somatosensory cortex. Cereb. Cortex 12, 395-410. doi: 10.1093/cercor/12.4.395

Wang, Y., Toledo-Rodriguez, M., Gupta, A., Wu, C., Silberberg, G., Luo, J., et al. (2004). Anatomical, physiological and molecular properties of Martinotti cells in the somatosensory cortex of the juvenile rat. J. Physiol. 561, 65-90. doi: 10.1113/jphysiol.2004.073353

Wedzony, K., Chocyk, A., Mackowiak, M., Fijal, K., and Czyrak, A. (2000). Cortical localization of dopamine D4 receptors in the rat brain-immunocytochemical study. J. Physiol. Pharmacol. 51, 205-221.

Wei, E. P., Kontos, H. A., and Said, S. I. (1980). Mechanism of action of vasoactive intestinal polypeptide on cerebral arterioles. Am. J. Physiol. 239, H765-H768.

Weihe, E., Tao-Cheng, J. H., Schafer, M. K., Erickson, J. D., and Eiden, L. E. (1996). Visualization of the vesicular acetylcholine transporter in cholinergic nerve terminals and its targeting to a specific population of small synaptic vesicles. Proc. Natl. Acad. Sci. U.S.A. 93, 3547-3552. doi: 10.1073/pnas.93.8.3547

Willi-Monnerat, S., Migliavacca, E., Surdez, D., Delorenzi, M., Luthi-Carter, R., and Terskikh, A. V. (2008). Comprehensive spatiotemporal transcriptomic analyses of the ganglionic eminences demonstrate the uniqueness of its caudal subdivision. Mol. Cell. Neurosci. 37, 845-856. doi: 10.1016/j.mcn.2008.01.009
Winzer-Serhan, U. H., and Leslie, F. M. (2005). Expression of alpha5 nicotinic acetylcholine receptor subunit mRNA during hippocampal and cortical development. J. Comp. Neurol. 481, 19-30. doi: 10.1002/cne.20357

Wonders, C. P., and Anderson, S. A. (2006). The origin and specification of cortical interneurons. Nat. Rev. Neurosci. 7, 687-696. doi: 10.1038/nrn1954

Wu, M. F., John, J., Boehmer, L. N., Yau, D., Nguyen, G. B., and Siegel, J. M. (2004). Activity of dorsal raphe cells across the sleep-waking cycle and during cataplexy in narcoleptic dogs. J. Physiol. 554, 202-215. doi: 10.1113/jphysiol.2003. 052134

Xu, Q., Cobos, I., De La, C. E., Rubenstein, J. L., and Anderson, S. A. (2004). Origins of cortical interneuron subtypes. J. Neurosci. 24, 2612-2622. doi: 10.1523/JNEUROSCI.5667-03.2004

Xu, Q., Guo, L., Moore, H., Waclaw, R. R., Campbell, K., and Anderson, S. A. (2010a). Sonic hedgehog signaling confers ventral telencephalic progenitors with distinct cortical interneuron fates. Neuron 65, 328-340. doi: 10.1016/j.neuron.2010.01.004

Xu, Q., Tam, M., and Anderson, S. A. (2008). Fate mapping Nkx2.1-lineage cells in the mouse telencephalon. J. Comp. Neurol. 506, 16-29. doi: 10.1002/cne.21529

$\mathrm{Xu}, \mathrm{X}$., and Callaway, E. M. (2009). Laminar specificity of functional input to distinct types of inhibitory cortical neurons. J. Neurosci. 29, 70-85. doi: 10.1523/JNEUROSCI.4104-08.2009

Xu, X., Roby, K. D., and Callaway, E. M. (2006). Mouse cortical inhibitory neuron type that coexpresses somatostatin and calretinin. J. Comp. Neurol. 499, 144-160. doi: 10.1002/cne.21101

Xu, X., Roby, K. D., and Callaway, E. M. (2010b). Immunochemical characterization of inhibitory mouse cortical neurons: three chemically distinct classes of inhibitory cells. J. Comp. Neurol. 518, 389-404. doi: 10.1002/cne.22229

Yaksh, T. L., Wang, J. Y., and Go, V. L. (1987). Cortical vasodilatation produced by vasoactive intestinal polypeptide (VIP) and by physiological stimuli in the cat J. Cereb. Blood Flow Metab. 7, 315-326. doi: 10.1038/jcbfm.1987.69

Yizhar, O., Fenno, L. E., Prigge, M., Schneider, F., Davidson, T. J., O’Shea, D. J., et al. (2011). Neocortical excitation/inhibition balance in information processing and social dysfunction. Nature 477, 171-178. doi: 10.1038/nature10360

Zilberter, Y., Kaiser, K. M., and Sakmann, B. (1999). Dendritic GABA release depresses excitatory transmission between layer 2/3 pyramidal and bitufted neurons in rat neocortex. Neuron 24, 979-988. doi: 10.1016/S08966273(00)81044-2

Zilles, K., Hajos, F., Csillag, A., Kalman, M., Sotonyi, P., and Schleicher, A. (1993). Vasoactive intestinal polypeptide immunoreactive structures in the mouse barrel field. Brain Res. 618, 149-154. doi: 10.1016/0006-8993(93)90438-S

Zupanc, G. K. (1996). Peptidergic transmission: from morphological correlates to functional implications. Micron 27, 35-91. doi: 10.1016/0968-4328(95) 00028-3

Conflict of Interest Statement: The authors declare that the research was conducted in the absence of any commercial or financial relationships that could be construed as a potential conflict of interest.

Received: 31 March 2014; paper pending published: 19 May 2014; accepted: 05 June 2014; published online: 24 June 2014.

Citation: Cauli B, Zhou X, Tricoire L, Toussay X and Staiger JF (2014) Revisiting enigmatic cortical calretinin-expressing interneurons. Front. Neuroanat. 8:52. doi: 10.3389/fnana.2014.00052

This article was submitted to the journal Frontiers in Neuroanatomy.

Copyright (c) 2014 Cauli, Zhou, Tricoire, Toussay and Staiger. This is an openaccess article distributed under the terms of the Creative Commons Attribution License (CC BY). The use, distribution or reproduction in other forums is permitted, provided the original author(s) or licensor are credited and that the original publication in this journal is cited, in accordance with accepted academic practice. No use, distribution or reproduction is permitted which does not comply with these terms. 